Transactions of the Royal Society of Edinburgh

http://journals.cambridge.org/TRE

Additional services for Transactions of the Royal Society of Edinburgh:

Email alerts: $\underline{\text { Click here }}$

Subscriptions: $\underline{\text { Click here }}$

Commercial reprints: Click here

Terms of use : Click here

Terms of use: Click here

\title{
XXXII.-Report on Fossil Fishes collected by the Geological Survey of Scotland in the Silurian Rocks of the South of Scotland
}

\author{
Ramsay H. Traquair
}

Transactions of the Royal Society of Edinburgh / Volume 39 / Issue 03 / January 1900, pp 827 - 864

DOI: 10.1017/S0080456800035237, Published online: 06 July 2012

Link to this article: http://journals.cambridge.org/abstract_S0080456800035237

How to cite this article:

Ramsay H. Traquair (1900). XXXII._Report on Fossil Fishes collected by the Geological Survey of Scotland in the Silurian Rocks of the South of Scotland. Transactions of the Royal Society of Edinburgh, 39, pp 827-864 doi:10.1017/

S0080456800035237

Request Permissions : $\underline{\text { Click here }}$ 
XXXII.-Report on Fossil Fishes collected by the Geological Survey of Scotland in the Silurian Rocks of the South of Scotland. By RAmsay H. TraquaIR, M.D., LL.D., F.R.S., Keeper of the Natural History Collections in the Museum of Science and Art, Edinburgh. (With Five Plates.)

(Read July 4, 1898.)

\section{INTRODUCTION.}

In the autumn of last year (1897), Sir A. GeIKIE, F.R.S., Director-General of the Geological Survey, kindly placed in my hands for description an important collection of fossil fish-remains from the Silurian rocks of the Lesmahagow district, which had been made by Messrs Macconochie and TaIr, collectors to the Survey. I accordingly prepared a brief report on these fishes, which was included by the Director-General in his Summary of Progress for that year.

The collection was, however, considerably increased by additional work on the part of Mr TAIT in the spring of the present year (1898). Many better and more complete specimens were procured, and I was able to define one new genus and species, which had previously been represented only by undeterminable fragments. The results gained by the examination of the entire collection I now propose, with Sir ARchibald GeIKIE's sanction, to lay before this Society in detailed form.

As might be expected, this collection is of the greatest importance both from a geological and from a zoological standpoint. Though I understand that Mr JAMES YoJNG of Lesmahagow had indeed found a fish in one of the beds, the "Ceratiocaris Band," before the collectors of the Geological Survey came on the scene, the only previous record, in any scientific publication, of the occurrence of such remains in the Scottish Silurian rocks is to be found in a paper (xii.) by the late Dr HunTER-SELKIRK of Braidwood, in which he mentions the finding of " a few small scales, something like those of Acanthodian tishes," in the rocks of Logan Water. Of special geological interest is also the fact, that while fishes of the family Coelolepidæ, represented by detached scales in the Upper Silurian rocks of England and Russia, occur in these Lesmahagow beds, no trace has as yet been found in them of the Pteraspidæ, the Cephalaspidæ, or of the Selachian spines and teeth which have been yielded by rocks of similar horizon elsewhere. Moreover, all the species and all the genera but one are new to science, and some of these throw unexpected light upon forms concerning which next to nothing was previously known. Others, too, are of appearance so strange that their precise place in the system has yet to be determined.

The fishes occur in special bands in the horizons designated by the Geological Survey VOL. XXXIX. PART III. (NO. 32). 
as "Ludlow" and "Downtonian," the latter forming the uppermost part of the Silurian system.

The localities are-

Ludlow-" Ceratiocaris" and "Pterygotus" bands in Logan Water.

Downtonian-Seggholm, Birkenhead Burn, Dippal Burn, Monk's Burn; in the Lesmahagow district. Lyneslie Burn in the Pentland Hills.

The fish-bands consist of hard, grey, flaggy shale, and in all the localities save Seggholm the actual substance of the fossils seems preserved. At the last-mentioned locality, however, the shale is somewhat decayed, and is in consequence soft, inclines to a brownish-yellow coloration, and the scales and plates of the contained fishes are only seen in impression.

It will serve our purpose best to begin with the description of the fishes themselves and of the facts concerning them, and thereafter to enter into the consideration of the bearing of these new facts on certain previously obscure questions in palæozoic ichthyology.

\section{PaRT I.-Descriptive.}

\section{Order HETEROS'TRACI, Lankester.}

Family Ceelolepida, Pander.

Head and anterior part of body flattened, trapezoidal, broader behind than in front; the sides forming posteriorly a right and left angular flap-like projection, the contour of which, sharply marked off from the tail behind, is continuous or nearly so with the lateral margin of the head. Tail narrow, provided with a deeply bifurcate and strongly heterocercal caudal fin. The flap- or lappet-like projections probably represent the pectoral members; but there is no trace of ventrals, or of dorsal or anal fins. Dermal covering, consisting either of minute shagreen-like scales having an internal pulp cavity, and usually a hole in the base, or of minute pointed conical spines, without any basal plate, hollow internally and widely open below.

There is no trace of teeth or jaws or of any internal skeleton except in one instance, the unique specimen of Thelodus Pagei of the Lower Old Red Sandstone of Forfarshire, which shows certain markings, probably caused by a branchial apparatus (xxxvi. p. 599).

This family was instituted by PANDER (xxi. p. 64) for the genera Cololepis, Pander; Thelodus, Agassiz; Nostolepis, Pander; and Pachylepis, Pander. Of these Nostolepis and Pachylepis are synonyms of Thelodus (Rohon, xxviii. p. 31), while Cololepis, in my opinion, falls under the same category (xxxvi. p. 601). These genera were founded on scattered scales, and nothing further has hitherto been known as to the creatures to which these scales belonged. The Cololepid scales have been considered to be "incertoe sedis" (Smith Woodward, xxxviii. p. 157), or to have belonged to sharks (M'Coy, xvii. p. 15 ; xviii. p. 576 ; Rohon, xxviii. p. 15 ; Reis, xxvi. p. 211), or to Acanthodians (Zittel, xliii. p. 30). Those who have referred the Cololepidæ to sharks have also been inclined to correlate with them the spines known as Onchus, which in England and Russia often occur in the same beds with the scales in question. 


\section{Genus THELODUS, Agassiz, 1839.}

Syn. Cololepis, Thelolepis, Pachylepis and Nostolepis, Pander.

Generic Characters.-Form of the body as in the definition of the family. Scales consisting of a base and of a crown separated by a constriction or neck. Crown of scale round, oval, quadrangular, or sometimes acutely pointed behind, smooth or sculptured; base usually with an opening of greater or lesser size (sometimes absent) leading into the central pulp cavity.

Range in time.-Although Thelodus is a characteristically Silurian genus, its range in time extends to the Upper Devonian, as Prof. RoHоN has described and figured scales of a species (Th. Tulensis) from strata of the latter age in Russia. I have also shown that the "Cephalopterus" Pagei of Powrie from the Forfarshire Lower Old Red belongs to the same genus (xxxvi.).

Remarks.-Although the name Thelodus, given to the detached scales in the Ludlow Bone Bed by Agassiz, implies that these little bodies are teeth, the laws of priority forbid its alteration into Thelolepis, as proposed by PANDER and adopted by RoHON.

For a more detailed account of the history of the genus I must refer the reader to my paper on Thelodus Pagei (xxxvi.).

\section{Thelodus Scoticus, Traquair. \\ Plate I. figs. 1-10.}

1898. Thelodus Scoticus, Traquair, in Director-General's Summary of Progress for 1897, p. 72.

Specific Characters.-Scales in front having the crown rounded, somewhat convex, smooth, the edges distinctly crenulated, the crenulation passing down the neck as a sort of fluting; base well developed with a conspicuous basal opening. Scales behind having the crown acutely pointed posteriorly, and sculptured with several longitudinal ridges and furrows.

- Note.-The anterior scales conform in general shape to the ordinary type of Thelodus scales, but the crenulations are fewer than in any which I have seen figured. The posterior scales resemble those of Thelodus (Coclolepis) Schmidti, Pander, in having their crowns pointed behind and longitudinally sculptured, but judging from Pander's and RoHоN's figures, the sculpture in these scales appears to consist of incised lines on a nearly flat surface, while in our present species the surface is convex and the ridges are sharp and elevated. It is interesting to reflect that were Thelodus Scoticus only known by detached scales, the two different forms of those bodies would certainly figure as distinct species.

Description.-Fig. 1 on Plate I. represents a specimen from the "Ceratiocaris Band" of the Ludlow horizon in Logan Water, which, though it shows the upper lobe of the caudal fin, is very deficient anteriorly; this is the largest specimen known, as its total length when entire would probably not be under $8 \frac{1}{2}$ inches. Fig. 2 is taken from a 
smaller specimen from the same horizon and locality, in which both lobes of the caudal fin are seen, but the general form of the body is somewhat obscure. The length of this specimen is $5 \frac{1}{4}$ inches.

In fig. 3 we have a small example from the Downtonian beds of Seggholm, which gives a very good view of the general shape of the entire creature, the pectoral fin-flaps and the deeply-cleft heterocercal tail being very conspicuous. Fig. 4 is a still smaller specimen from Monk's Burn, in which the tail is also very well exhibited, but the pectoral flaps are rather drawn in.

The length of the head and body to the posterior origin of the pectoral fin-flaps is contained on an average rather less than three times in the total, while the caudal fin, with its two lobes, occupies also rather less than the terminal third of the fish.

In some specimens, as in fig. 3 , the apices of the pectoral fins seem rounded, but in most, as in fig. 4, they are angulated, and this latter condition I take to represent the normal and unaltered contour. As to the caudal fin, both lobes are pointed, and the upper one is longer than the lower.

Owing to the state of preservation of the specimens, there are few opportunities of making out the exact form of the scales, an obscurely granulated surface being very often all that is shown by the dermal covering. Careful examination, however, of a considerable number of specimens reveals not only the shape of the scales, but the fact that the scales on the head are of a different form from those further back. I was fortunate enough to find both forms of scales together in an iron-stone nodule from Logan Water, imbedded in a softish material, considered by Mr B. N. PEACH to be coprolitic in its nature, and with a little trouble I succeeded in isolating the scales represented in Pl. I. figs. 6-9. On comparing these with the scales and impressions of scales which are now and then to be seen in the entire fishes themselves, there can be no doubt as to the identity of the species.

The anterior or head-scales (figs. 5-7) have the regular Thelodus form, with welldereloped base and conspicuous basal opening (fig. 6); a smooth, slightly convex crown (fig. 5), separated from the base by a constricted neck, as seen in fig. 7. It will be seen that the edges of the upper surface show eight or nine shallow crenulations or crimpings, which are continued down the neck as a sort of "fluting," very much as in the scales of Th. Pagei.

Fig. 8 represents one of the posterior scales seen from above, and fig. 9 a similar one seen from the side. They can be absolutely identified with those which are sen beautifully preserved in situ in some parts of the fish represented in fig. 1, and whose arrangement is represented in fig. 10 .

These scales are very small, the examples figured measuring only $\frac{1}{50}$ inch in long diameter. The crown is rounded in front, pointed behind, where it projects backwards over the basal part,-convex above, and longitudinally ribbed in such a manner as to remind one of some small umbelliferous seed. The usual mode of ribbing is this:-Each side of the upper surface is constituted by a marginal ridge, inside which and at a some- 
what higher level we have a second pair of ridges running parallel to the first, and also meeting behind in a point, while, lastly, between them is a longitudinal median depression. The base is shallow, but I have not got a good view of its under surface.

Observations.-The specimens from the Downtonian beds of Birkenhead Burn, Seggholm, etc., though well preserved as to external form, do not show the configuration of the scales in so distinct a manner as those from the Ludlow horizon in Logan Water; it is therefore not beyond the bounds of possibility that they may ultimately turn out to belong to another though closely allied species. Meanwhile, to avoid premature multiplication of names, I associate them with the Logan Water examples which constitute the types of Scoticus.

Position and Localities. - In the Pterygotus Band and in the Ceratiocaris Band in Logan Water; also in the Downtonian beds at Seggholm, Birkenhead Burn, and Monk's Water.

I may mention that I have lately, while examining some specimens of the wellknown "Bone Bed" from Ludlow, found one or two scales which resemble the posterior ones of this species to a very close degree.

\section{Thelodus planus, Traquair. \\ Plate II. figs. 1-3.}

1898. Thelodus planus, Traq., in Director-General's Summary of Progress for 1897, p. 74.

Specific Characters.-Upper surface of anterior scales round or somewhat oval, slightly convex, smooth; scales behind becoming narrow, elongated, and pointed posteriorly, but without any strongly marked sculpture.

Description.-Fig. 1, Plate II., represents the only specimen of this form which has as yet been obtained. It measures seven and a half inches in length, but as the extremity of the tail is imperfect, it must originally have been at least two inches longer. The contour of the fish is pretty clear, although the edges are somewhat ragged; the lower lobe of the caudal fin is gone, while only the beginning of the upper one is preserved.

The scales are very small, and are represented magnified eight diameters in figs. 2 and 3 of the same plate. Unfortunately no view can be had of any of them, either from below or from the side-all are either broken through or show the upper surface only. In those of the head (fig. 2) this upper surface is round or oval, smooth, ganoid, slightly convex, and with an occasional tendency to crenulation round the edge, while in the posterior scales (fig. 3) the exposed surface is more elongated, is pointed posteriorly, and in some cases even a trace of a ridge on each side close to the margin may with some care be made out. As shown in the figure, these scales seem to be somewhat irregular in size.

This species is distinguished from Th. Scoticus by the smoothness of the posterior scales, the species to which it is most allied being Th. glaber (Pander), from the Upper Silurian of Oesel.

Position and Locality.-From the Ceratiocaris Band in Logan Water. 


\section{Genus LANARKIA, Traquair, 1898.}

Contour of head, body, tail, and fins as in Thelodus. Dermal armature consisting of small, sharp, conical spines, hollow within and widely open below, without basal plate.

The generic name is taken from the County of Lanark, in which the fish-bearing Silurian beds are situated.

\section{Lanarkia horrida, Traquair. \\ Plate III. figs. $1-6$.}

1898. Lanarkia horrida, Traq., in Director-General's Summary of Progress for 1897, p. 73.

Specific Characters. - Dermal spines mostly of one size, large for the size of the fish, and with expanded, somewhat trumpet-mouth shaped base.

Description.-This is a small species, the length of which seldom exceeds two inches, while the proportionally large size of its spines gives it a very decidedly prickly appearance.

Fig. 1, Plate III., represents a specimen from Birkenhead Burn, in which the form of the head and pectoral region is more than usually undistorted, but the caudal fin is absent. This deficiency is, however, supplied in fig. 2, in which it will, however, be observed that the parts in front are pressed somewhat awry. Both figures are enlarged by one-half.

The spines are nearly equal in size all over the fish, save on the pectoral and caudal fins, where they are smaller. On the pectoral fins there is also some appearance of smaller spines intermixed with the larger ones. These appendages (figs. 3-6) have a widely open trumpet-mouth-like base which passes, usually in an oblique manner (fig. 3), up into a conical pointed shaft, which is externally finely striated longitudinally (fig. 4). Fig. 5 represents a natural cast or impression of the interior of the base of one of those spines with the shaft broken off, and in fig. 3 a portion of the wall of the spine has flaked away, showing the mould of the cavity within. Fig. 6 represents a group consisting of three moulds of the interior and two impressions of the exterior of similar spines.

Position and Localities.-Downtonian Beds at Birkenhead Burn and Seggholm.

Lanarkia spinosa, Traquair.

Plate III. figs. 7-12; Plate IV. figs. 1-2.

1898. Lanarlicia spinosa, Traq., in Director-General's Summary of Progress for 1897, p. 73.

Specific Character.-Skin closely covered with minute pointed spines, among which are scattered, in varying degrees of closeness, spines of a larger size, which are also conical pointed and striated externally. 
Description.-This is a larger species than the former, some of the examples in the collection attaining a length of six inches. In general form it is identical with $L$. horrida, but the manner in which that form may be altered by distortion is well seen in the examples figured in Pl. III. figs. 7 and 8, and Pl. IV. fig. 12. My idea of the undistorted form is given in the accompanying restored outline.

The small spines are extremely miute, the larger ones (Pl. III. figs. 10-12) are very similar to those of the preceding species, though not quite so trumpet-shaped; they

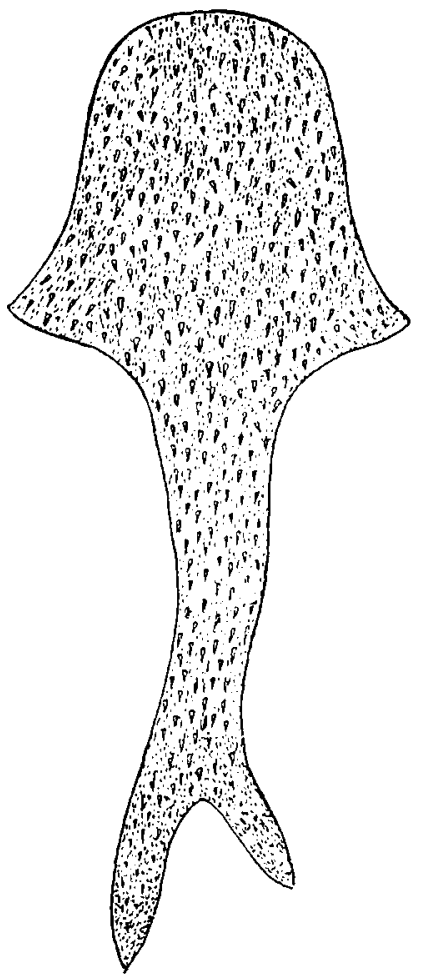

FIG. 1.-Restored outline of Lanarkia spinos $\alpha$ in the position in which "it occurs as a fossil, namely, vertically compressed in front, but the tail twisted round so as to appear in profile.

are also hollow internally and minutely striated externally. The manner in which they are interspersed among the smaller ones is shown in fig. 9 of this plate and in fig. 2 of Plate IV.

Position and Localities.-From the Downtonian Beds of Seggholm, Birkenhead Burn, and Monk's Burn.

Lanarkia spinulosa, Traquair.

Plate IV. figs. $3-5$.

1898. Lanarkia spinulosa, Traq., in Director-General's Summary of Progress for 1897, p. 73.

Specific Character.-All the dermal spines minute, and without admixture of larger ones. 
Description.-As yet very few examples of this species have occurred, and of these not one is entire. The specimen represented in Pl. IV. fig. 3 shows a large portion of the fish, but is imperfect both in front and behind: from what remains we may judge that its original length was seven or eight inches. The whole surface is closely covered with minute, sharp, conical, striated spines, as seen magnified in fig. 4 , and still further enlarged in fig. 5.

Badly preserved specimens of Thelodus Scoticus and Lanarkia spinulosa are sometimes difficult to distinguish from each other.

Position and Localities.-Downtonian Beds at Seggholm and Birkenhead Burn.

ORDER OSTEOSTRACI.

Family Ateleaspida.

Genus ATELEASPIS, n. g., Traquair.

Imperfectly known. General form of body apparently as in the Cœlolepidæ, but the dermal covering in front consists of small polygonal plates, while behind the pectoral fin-flaps it takes the form of flat rhombic sculptured scales. Orbits apparently on the top of the head as in Cephalaspis.

\section{Ateleaspis tessellata, n. sp., Traquair. \\ Plate IV. figs. 6-12.}

In my preliminary report (p. 74) I referred to "one or two fragments showing quadrangular osseous scales belonging to some other fish," no doubt undescribed. On account of the very fragmentary nature of those specimens I abstained from giving them a name, as well as from entering any further into their description.

Since that report was written, Mr TAIT was successful in obtaining a specimen at Seggholm, which I think I am justified in identifying with these fragments, and which, imperfect as it is, throws a certain amount of light on what is apparently a very remarkable fish.

Description.-The most perfect specimen is represented of the natural size in $\mathrm{Pl}$. IV. fig. 6, and shows the anterior portion, including the pectoral fin-flaps, in a tolerable state of completeness; the tail is, however, obliquely cut through on the right side. We have here in front a contour essentially similar to that in Thelodus or Lanarkia, though the pectoral flaps appear to be a little more rounded. When examined by a lens, the surface appears covered with small polygonal tesseræ, which are not all of the same size or of the same number of angles, and these tesseræ wcre evidently covered with minute, closely-set, rounded tubercles. As there is scarcely any of the original bony matter left in the fossil, a study of the counterpart is necessary towards coming to a conclusion as to the condition of the surface. In the same Plate, fig. 9, we have a very little bit of the counterpart magnified five times, showing distinctly the impression of the tesseræ and 
'of their tubercular ornament. Fig. 10 again represents a "squeeze" in modelling wax taken from a similar pice of the counterpart, the tubercles appearing here in relief. The tesseræ become extremely small and at last indistinguishable on the parts corresponding to the fin.flaps in the two preceding genera; and it is also to be noted that tubercles of a larger size are to be seen in impression along the lateral and anterior margins of the head.

About the middle of the head there are to be seen, on the counterpart, two small crescentic markings, right and left, separated from each other by a space of one-third of an inch, and situated balf an inch back from the front, the convexity of each being outwards and the concavity inwards. These markings, indicated in the accompanying outline, certainly do suggest the outer margins of a pair of orbits placed as in Cephalaspis, and on no other supposition can I explain their presence, although there is no trace of any inner margin to either, nor of any orbital space or opening, the impressions of the

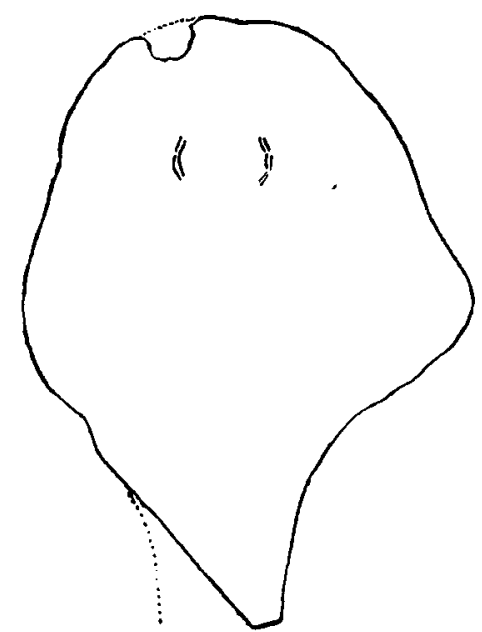

FIG. 2. Outline sketch of the counterpart of the specimen of Ateleaspis tessellata, to show the position of the crescentio marking alluded to in the text.

tuberculated tesseræ being continued all over the intervening surface. This may, however, be due to that vertical pressure which has reduced to absolute flatness a contour which was no doubt originally more or less elevated or vaulted in the middle; it must, however, also be noted that there is no trace here of the ant-orbital fossæ or of the postorbital valley which are prominent markings on the shield of Cephalaspis.

On the tail the dermal covering assumes the form of rhombic scales arranged in transverse rows, and the change from the polygonal tesseræe to this condition is seen to occur already in front of the posterior margins of the pectoral fin-flaps. In Pl. IV. fig 11 portions of three rows of these scales are represented, magnified three diameters, the drawing being made from a "squeeze" in modelling wax taken from the counterpart. As here exhibited, the sculpture of the surface consists of comparatively coarse, wavy, and tortuous ridges, tubercles and furrows, which pass across the scale from before backwards.

Fig. 7 represents a fragment apparently of the caudal part of a larger fish near its

VOL. XXXIX. PART IIT. (NO. 32). 
origin. Part of the original osseous matter of the scales still adheres to the matrix, so that their sculpture (Pl. IV. fig. 12, magnified three diameters) is not properly seen ; however, as far as one can judge, it is similar to that of the scales represented in fig. 11, though the ridges seem finer and more numerous.

Fig. 8 of the same plate is another fragment, which is evidently the upper lobe of a forked caudal fin, shaped like that of Thelodus or of Lanarkia. The scales on the body-prolongation are mostly rhombic, though sometimes nearly square in form, and show traces of an ornamentation resembling that in the two former specimens. On the part corresponding to the fin-membrane the scales become very small, and assume a more or less linear arrangement.

Microscopic Structure.-In a vertical section of scales from Birkenhead Burn which are evidently referable to this species, I distinguish three laycrs:-an upper, consisting of sections of the superficial tubercles and ridges; a middle, or cancellated layer; and a lower, or laminated one. The ridges and tubercles which make up the outer layer are usually solid in section, though sometimes hollow at the base, and are permeated, but not very closely so, by branching tubules, which pass in a radiating manner from the base to the periphery. In most cases, and especially towards the base of the tubercle or ridge, these tubules are seen to be provided with irregular dilatations which also give off other branches, and which cannot in fact be removed from the category of lacunx or "bone-cells," however much they may differ from the orthodox lacunæ in their frequently irregular shape. In a few instances the tubules seem towards the base of the tubercle to be merely very coarse, without the presence of distinctly differentiated lacunæ, but that is rare. There is no surface layer of ganoine. The middle layer consists of a cancellated or spongy tissue in which distinct structure is hard to discern; the lower layer seems to be composed of thin laminæ superimposed upon each other, with obscure, elongated specks between, which I have no doubt are also lacunæ. I hope to figure these interesting details on a future occasion.

Observations. - In general form Ateleaspis resembles the Cololepidæ, but on the head the shagreen-bodies have coalesced into small polygonal plates,-behind, into flat rhombic scales: the thickness of these plates and scales being added to by ossification in a deeper layer of the skin. The tessellated aspect of the head-covering reminds us both of Cephalcespis and Psammosteus, but the position of the crescentir markings, which apparently indicate the outer margins of the orbits, shows a greater affinity with the former genus, which is confirmed by the microscopic examination of the scale, which discloses presence of undoubted bone-lacunæ with branching processes. There are, however, neither lateral cornua, nor post-orbital valley, nor pre-orbital fossæ; but as we seem to have here an approximation to the formation of a shield like that of Cephalaspis, I propose for the genus the name of Ateleaspis, or "imperfect shield"

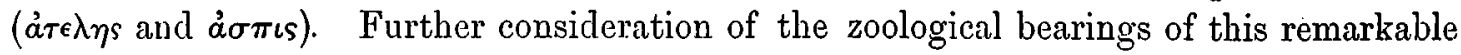
form I reserve for the second part of this paper.*

* The paragraphs above designated as "Microscopic Structure" and "Observations" have been rewritten since the 
Position and Localities.-All the specimens figured are from the Downtonian Beds of Seggholm, though there is also in the collection a fragment from the beds of similar age at Birkenhead Burn. Mr 'TAIT has also recently collected a few detached scales from the Downtonian Beds of the Pentland Hills. It is unfortunate that a fish of such interest and importance should be so exceedingly rare, and the specimens as yet obtained so comparatively fragmentary.

\section{Order ANASPIDA.}

The two remarkable genera to be now described are so unlike any other fishes hitherto known that I feel under the necessity of erecting a new order for their reception. And as one of these forms, Birkenia, presents some features reminding us of Cephalaspis, we may as well, at least provisionally, place the order also in the sub-class Ostracodermi. Nevertheless, the structure of the substance forming dermal scales of Birkenia shows neither the bone-lacunæ of the Osteostraci nor the dentine tubules of the Heterostraci, but so far as I have been able to examine them microscopically, nothing is seen but a homogeneous, or slightly fibrillated mass, though this may possibly be the result of faulty preservation.

\section{Family Birkeninde.}

Small fishes, fusiform in shape, with deeply bifurcate beterocercal caudal fin, but no paired limbs. Dermal hard parts in the form of scutes, which are in one form nearly entirely absent. No cranial shield; orbits, jaws, and internal skeleton unknown.

Genus BIRKENIA, Traquair, 1898.

Generic Charcucters.-Fusiform; body covered with several longitudinal rows of narrow scutes, arranged in lines running obliquely from above downwards and forwards; head bluntly rounded, also covered with narrow scutes; an oblique row of small round openings on the side just at the posterior boundary of the head; no orbit seen, and no evidence of cranial bones, jaws or shoulder-girdle; no paired fins; caudal palæoniscoid in shape, completely heterocercal, deeply bilobed and rayed; a small rounded dorsal situated far back, near the caudal.

\section{Birkenia elegans, Traquair.}

Plate V. figs. 1-4.

1898. Birkenia elegans, Traquair, in Director-General's Summary of Progress for 1897, p. 73.

Specific Characters.-Scutes finely tuberculated; five rows on the sides of the body, of which the upper two do not pass beyond the dorsal fin; a row of six median scutes between the anal region and the origin of the lower lobe of the caudal fin, each paper was presented to the Society, and also since the publication of my notes in the Geological Survey's Memoir on the Silurian Rocks of Scotland. 
furnished with an aculeate spine, first one being directed forwards, the remaining five backwards.

Description. - The specimen represented in Pl. V. fig. 1, enlarged by one-half, is three and a half inches in length, and is the largest complete one in the collection, though fragments occur indicating a somewhat larger size. This example does not show the contour of the head properly, but that deficiency is supplied in fig. 2, in which the rounded blunt form of that part is seen in its entirety. Fig. 3 represents another small specimen, the contour of which is shortened up, a phenomenon which, as well as the converse condition of lengthening out, is frequently observed in palæozoic fishes which had no ossified vertebral column to keep them in shape during fossilisation.

The configuration of the fish and the arrangement of its dermal scutes may best be understood by a reference to the accompanying restored outline, the contour of which is based on that of the specimen represented in Pl. V. fig. 1, the details being, however, completed by an examination of numerous other examples.

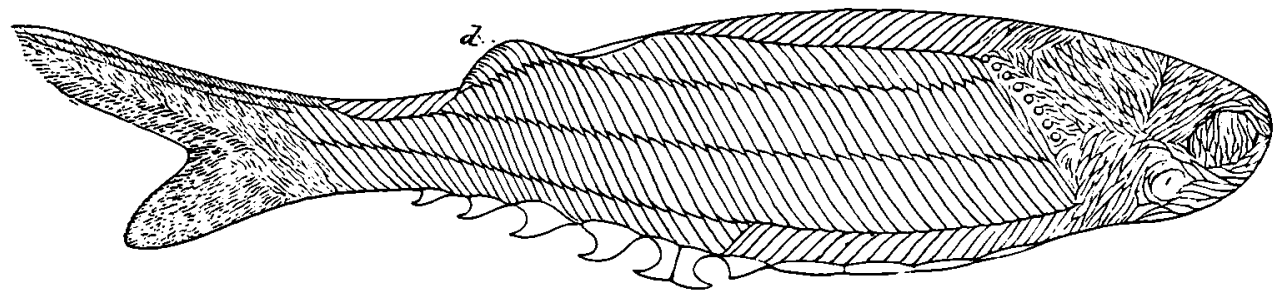

Fra. 3.-Restored outline of Birkenia elcgans, Traq., one-half larger than natural size; $d$, dorsal fin.

From the elegantly fusiform shape of the body and the completely heterocercal deeply cleft inequilobate caudal fin, we might at first sight fancy that we had before us a member of the Palæoniscid family, with the rows of scales running the wrong way! The resemblance is, however, entirely superficial.

The head is bluntly rounded, and covered with small scutes, spindle-shaped in -outline, and very peculiarly arranged. On the top of the head they are disposed in four areas separated by two cross lines, one longitudinal-median and the other transverse-the scutes of each area having their long axes parallel with each other, but directed at acute angles to those of its fellow of the opposite side, and also of the :area immediately in front. Of course, in the figure only the two areas, anterior and posterior, of the right side can be seen. Then in front, just behind the rounded snout, the little scutes swirl round a circular space nearly where we would expect the orbit of a palæoniscid fish to be, but the area of this space is occupied by scutes like those of the rest of the head, but arranged with their long axes vertical. Below and behind this space is another rounded marking, around which the adjacent scutes also pass in a swirling manner, but what organ this can represent it is meanwhile impossible to guess. It is on the wrong aspect of the head for an orbit,-it cannot be a mouth, because it is paired, having a fellow on the opposite side. It is not even certain that 
it is an opening at all. Immediately behind this the rest of the head is covered by an area of little sciutes, which have their long axes directed downwards and backwards.

Now a narrow band-like prolongation of this last-mentioned area passes obliquely upwards and backwards along the posterior margin of the head as far as the first row of body-scutes. In this band we see, in every specimen, eight small round openings or their impressions. Are these branchial openings? That is indeed the only interpretation which I am able to put upon them.

In no specimen can any trace of mouth, of jaws, or of teeth be found, nor is there any certain evidence of eye-orbits.

Passing now to the body, we find that it is covered on each side with five longitudinal rows of scutes, which are much larger than those on the head, and of a narrow, elongated oblong shape, pointed at each end.

Commencing above, the first row extends from the back of the head to within a short distance of the dorsal fin. It consists of a succession of narrow parallel plates, whose long axes are directed from above downwards and backwards, that is, in a direction contrary to that of most of the scutes of which the other rows consist. This row is in contact in the middle line of the back with the corresponding series of the other side. The second row proceeds below the first as far as the dorsal fin, in fact passes into that appendage; the direction of its parallel scutes is downwards and forwards. So it is with the scutes of the third row until they pass the dorsal fin, when, from that point to the termination of the series on the tail pedicle, their direction is suddenly altered, and their long axes point downwards and backwards. The fourth series, which extends right back from the head to the tail pedicle, has its scutes directed downwards and forwards from beginning to end without interruption. The fifth row, which runs along the ventral margin from the head also to the tail pedicle, consists of scutes which in the front half of the fish point downwards and backwards, but exactly in the middle of the ventral curve the direction is suddenly reversed and the scutes come to have their long axes directed downwards and forwards until the band ends at the caudal fin.

In the middle line of the back, and placed exactly between the termination of the first row of body.scutes and the dorsal fin, is a single narrow oblong azygous plate.

Then on the opposite aspect of the body we have on the front half of the ventral curve five marginal scutes, of which the first four are narrow and spurless, while the fifth rises into a backwardly directed sharp conical elevation. So far as I can judge, these scutes seem to be placed on one side of the middle line, leaving us therefore to suppose that they are paired structures, but this I cannot prove, as in no specimen are their fellows of the opposite side to be seen, and analogy with Lasanius would lead us on the other hand to suppose that they formed one continuous series with the remaining five marginal scutes behind them, which undoubtedly are placed in the middle line, and are remarkable for the prominent thorn-like spine borne by each. The first one of these is apparently formed of two closely fused together, the two halves-anterior and pos- 
terior-being separated by a vertical line, and each bearing a thorn, that of the front half being directed forwards, that of the hinder part backwards. The succeeding four scutes which lie between this double one and the tail pedicle gradually diminish in size, but each of them rises into a prominent backwardly curved and pointed thorn, of a rather formidable appearance it must be owned.

The dorsal fir forms a small rounded projection from the outline of the back, and is situated far behind, so as to be just in front of the tail pedicle. Its " rays" are simply continuous with the scutes of the body, in fact they belong to the second lateral row, but tend to become broken up distally.

The caudal fin is palæoniscoid in shape, being deeply cleft into two unequal lobes, of which the upper is the longer and contains the prolongation of the body axis, from the under aspect of which the fin-membrane exclusively arises. The body-prolongation is covered by innumerable minute rhombic or spindle-shaped scales, which result from the breaking up of the third, fourth and fifth series of lateral body-scutes. Along the dorsal margin we have a special band of tiny narrow oblique scales, which would remind us of the ridge-scales or "fulcra" of the upper lobe of a palæoniscoid tail, were it not that the band here apparently consists of two rows of scales one above the other. The finmembrane is also covered with narrow scales which tend to be arranged linearly so as to give the fin a very decidedly rayed appearance. All the scales of the tail and of the caudal fin show the same minutely tuberculate ornamentation which occurs on the scutes of the body.

Position and Localities.-Extremely rare in the Ludlow horizon, one specimen only having been found by Mr TAIT in the "Cerctiocaris Band" at Shanks Castle, Logan Water. It is, however, by far the most common of the fishes which occur in the overlying Downtonian rocks, and has been obtained in that horizon in the following localities in Lanarkshire-Slot Burn, Seggholm ; Birkenhead Burn; Dippal Burn ; Monk's Burn. Detached scales have also occurred in the Downtonian of the Pentland Hills, at Lyneslie Burn, near its junction with the Lyne Water.

\section{Genus LASANIUS, 'Traquair.}

Generic Characters.-Elongated-fusiform in shape, with a deeply cleft heterocercal caudal fin. A median row of ventral scutes, each bearing a recurved thorn, runs along the ventral margin from behind the head to the origin of the caudal fin. Immediately behind.the head is a series of eight slender parallel bony rods on each side, and directed downwards and forwards, each of which at its dorsal extremity sends a process inwards to the middle line of the back, there meeting its fellow of the opposite side. In front of the anterior one of these rods, and parallel with it, is a chain of short slender ossicles. No other hard parts are visible, but the form of the body is often more or less indicated by a delicate carbonaceous film.

[At first, judging from the position of the median aculeated scutes in Birkenia, 
I thought it probable that they also occupied a ventral position in Lasanius; afterwards, however, it seemed to me more natural to suppose that such a long row of median thorny plates should run along the back instead of along the belly. The matter was, however, settled by a specimen of a new species of the same genus obtained by Mr TAIT since the beginning of the year 1899, and, in consequence, the description of Lasanius has been rewritten since this paper was presented to the Society.]

\section{Lasanius problematicus, Traquair.}

Plate V. figs. 5-11.

1898. Lasanius problematicus, Traq., in Director-General's Summary of Progress for 1897, p. 73.

Specific Characters. - Eighteen median scutes along the ventral line, aculei slender.

Description.-In ordinary specimens only two things are to be seen-the long row of median scutes and the arrangement of parallel rods in front-and though these always maintain the same relative position, it was impossible so long as no other parts were observed to decide as to which was the dorsal and which the ventral aspect of the fish. That the line of scutes is, however, ventral is proved by the occurrence of a specimen of the closely-allied species $L$. armatus, in which the arrangement of the rays of the heterocercal tail-fin can be clearly detected.

Pl. V. fig. 5 represents a typical specimen showing the position of the oblique rods lying above, and passing beyond the anterior extremity of the row of rentral scutes; the same relations are also shown in the restored outline, fig. 4 , in the text.

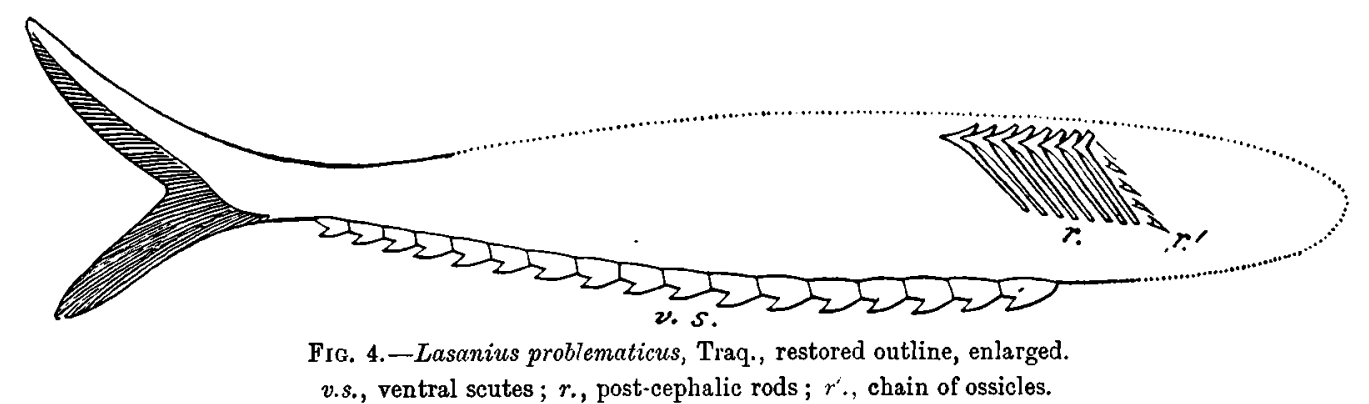

These rods (see also figs. 7 and 8) are eight in number, and consist each of two parts or limbs, which meet above at an angle which increases in acuteness as we pass backwards along the series, and, where the two parts join, there is a sharp posteriorly directed process. The lower limb, slender and tapering, is directed obliquely downwards and forwards on the side of the fish,---the upper one is on the other hand short and directed inwards (fig. 7) to meet its felluw of the opposite side in the middle line of the back. In front of the foremost rod there runs parallel with it a row of five or six small ossicles, the lower extremity of each of which rides over the upper extremity of the one below, and each of them (fig. 9) is also furnished with a small backwardly directed thorn-like projection. 
The median scutes are eighteen in number; they are oblong in form when seen from above or below, and the anterior extremity of each overlaps the posterior margin of the one in front, a mode of imbrication with which we are unacquainted as regards the scales of other fishes. Each of these plates is hollowed on its attacbed surface, elevated on its free aspect, and there it is provided (figs. 10 and 11) with a sharp backwardly directed thorn or aculeus. I have not observed any evidence of external sculpture in those scutes.

In a considerable number of specimens a delicate carbonaceous film indicates in parts the remains of the soft tissues and gives a clue as to the external form of the fish. It is thus clear that the head extended a little way beyond the oblique rods, and that it was, as in Birkenia, bluntly rounded in front. In the same way the caudal fin is seen to commence just at the posterior termination of the ventral row of scutes, and to be heterocercal, deeply divided into two slender lobes, of which the upper one is considerably the longer. This is well shown in fig. 8 , but it is in the species next to be described that the actual fin rays have been observed.

As regards size, specimens have occurred so small as to have the row of ventral scutes only three-quarters of an inch in length, whereas in large examples this may extend over a length of two inches and a quarter.

Position and Localities. - Only in the Downtonian horizon, in which it occurs in the same localities with Birkenia, Ianarkia, etc. ; Birkenhead Burn; Slot Burn, Seggholm; Dippal Burn; Monk's Burn; Smithy Burn, Hagshaw Hill. In the Pentland Hills detached scutes have been found by Mr TaIT at Lyneslie Burn, along with similar scattered remains of Birkenia and Ateleaspis.

Lasanius armatus, sp. nov., Traquair.

Plate V. figs. 12, 13.

Specific Character.-Aculei of ventral scutes, thick and stout.

Description.-Two specimens only have occurred, both of which are very small, the more perfect one being only $1 \frac{1}{8}$ inch in length, including head and caudal fin, while. the other would probably have given the same measurement had it not been cut off by the edge of the stone before the termination of the ventral scutes.

The first mentioned specimen is represented in Pl. V. fig. 12, magnified three diameters. It will be seen that the shape of the body is pretty well shadowed out by a dark film, the form of the head being slightly distorted. I attach no significance to the two round spots without film seen near the front of the head. The oblique rods are seen in their proper position; below them commences the ventral row of scutes, and these are seen to have their thorns disproportionally large when compared with those of L. prollematicus. The shape of the individual thorns is better shown in the second specimen, from which fig. 13 is taken, and which represents one of these plates with its thorn seen from the side, and magnified four diameters. This difference in the ventral 
aculei is not a matter of age, for the smallest specimens of $L$. problematicus have slender thorns, just as in adult examples.

The condition of the caudal fin is here of prime interest, for on wetting the specimen and examining it with a lens, the arrangement of its rays can distinctly be seen. And so, if we are to judge from the analogy of other heterocercal fish-tails, the arrangement here seen at once shows that the azygous row of scutes is on the ventral side of the body. In other words, we see the body-prolongation distinctly passing into the longer lobe of the fin, which is on the opposed side to the scutes, the rays of this lobe being short, while those of the smaller lobe are long.

Position and Locality.-Downtonian Beds at Slot Burn, Seggholm.

\section{Part II.-Results.}

\section{The Ceelolepide.}

The general form of the Cœlolepidæ has now been ascertained. They are shark-like fishes of comparatively small size, the largest example known being only fourteen or fifteen inches in total length. The head, with the anterior part of the body, is depressed, the pectoral fins are lappet-like, there is a strongly heterocercal caudal, but no other fins. The dermal covering is seen in its most primitive form in Lanarkia, where it consists of small hollow-pointed spines, open below, and without basal plate. It appears in a more specialised form in Thelodus, where we have small shagreen-like scales constricted below the crown, with a base more or less developed, in which there is usually an opening into a central pulp cavity. Where their microscopic structure has been examined, these scales are found to consist of simple dentine, with radiating tubules, with no Haversian canals ; the crown is also covered with a layer of ganoine. No traces have been seen of jaws, teeth, eyes, branchial openings, or internal skeleton. The last-mentioned part of the organism must have been entirely cartilaginous.

In the absence of hard circumorbital plates, of teeth, and of opercula, it is not surprising that the position of the eyes, of the mouth, or of the branchial openings should not be ascertainable, though in the Devonian Thelodus Pagei (xxxvi. p. 599) the position of the branchiæ themselves seems to be indicated by certain transverse markings in the broad and depressed anterior part of the fish.

Of course the notion that the Selachian spines known as Onchus, or the teeth, which have been named Monopleurodus and Anchistrodus, had anything to do with the Cololepidæ, is now entirely disposed of. Nevertheless, looking at these fishes as a group by themselves, and taking into special consideration the nature of their dermal covering, we should have no hesitation in assigning to them a position among the Selachii, and, as Selachians I classed them in my preliminary notice of the Lesmahagow fishes.

In that notice I also applied to them the term "primitive." If that is so, then the VOL. XXXIX. PART III. (NO. 32). 
lappet-like appearance of the flaps, which I have interpreted as pectoral fins, would give a new and important corroboration to the lateral fold theory of the paired limbs, and would present us with a "ptychopterygium" still more archæic than the pectorals of Cladoselache, as described and interpreted by BAshFord DEAN and others.

Whether the Coelolepidæ are admissible to a place among the Selachii or not, the nature of their dermal hard parts points directly to an Elasmobranch affinity and Elasmobranch derivation. But their "primitive" nature now seems to me, on reconsideration of the subject, extremely doubtful. In fact, the depressed configuration of the anterior part of the fish, the absence of teeth, and of ventral, dorsal, and anal fins seem to me to be rather marks of a very considerable specialisation than of archæic simplicity. In this way the lappet-like fin-flap may well represent a degenerate form of pectoral fin instead of an original ptychopterygeal form of that member.

And as the Coelolepidæ seem also to be so inseparably linked to a series of organisms whose typical representatives can hardly be looked upon as Selachii, hardly even as Elasmobranchs, I prefer to consider them as having definitely split off from the last named sub-class, from which they doubtless originally came.

\section{The Drepanaspides.}

We may now take up the consideration of the Drepanaspidæ, a family the sole representative of which is the singular genus Drepanaspis of Schliiter, from the Lower Devonian slates of Gmünden, in Western Germany.

Drepanaspis Gmündenensis has bitherto been scarcely known to science. It was named, but very imperfectly described, also without figures, in 1887 by Prof. ScHLÜrer of Bonn (xxx.), who seemed to consider it as allied to Cephalaspis. In Mr SMITH WoodWARD's Catalogue, Part II. p. 311, it is only mentioned by name and placed along with a number of other imperfectly known forms (Aspidichthys, Anomalichthys, \&c.), which he considered as "perhaps for the most part" referable to the Coccosteidæ. In 1896 I noticed the fish before this Society,* and expressed the opinion that its affinities lay rather with the Pteraspidæ, a view which I am now prepared to defend and confirm, as well as to point out that on the other hand Drepanaspis is likewise related to the Cololepidæ.

I have now, by the help of Mr B. STüRTz of Bonn, got together, in the Edinburgh Museum of Science and Art, an important series of specimens of Drepanaspis from Gmünden, and I have also to thank my friend, Prof. O. JAEKEL, for procuring for me some beautiful casts of examples in the Natural History Museum at Berlin, and also in the collection of the Geological Survey in that city. I hope presently to use this material for a more exhaustive description of this remarkable form; meanwhile I shall indicate the principal points in its construction, as far as ascertainable, by the aid of the accompanying restored sketch of its dorsal aspect.

\footnotetext{
* Nature, vol, liv., 1896, p. 263.
} 
The remains of Drepanaspis Gmündenensis occur in a pyritised condition in the dark purple roofing-slate (Hunsrückschiefer) of Gmünden, a mode of preservation which, though yielding beautiful fossils to laborious and careful preparation, forbids their affording any results to microscopic examination. It was a fish of considerable size, and large examples must have attained a length of over two feet.

From the accompanying sketch it will be seen that, as in Thelodus, the fish is divided into two parts-an anterior, broad and depressed, corresponding to the head and body, and a posterior, or tail, terminating in a heterocercal caudal fin. The anterior

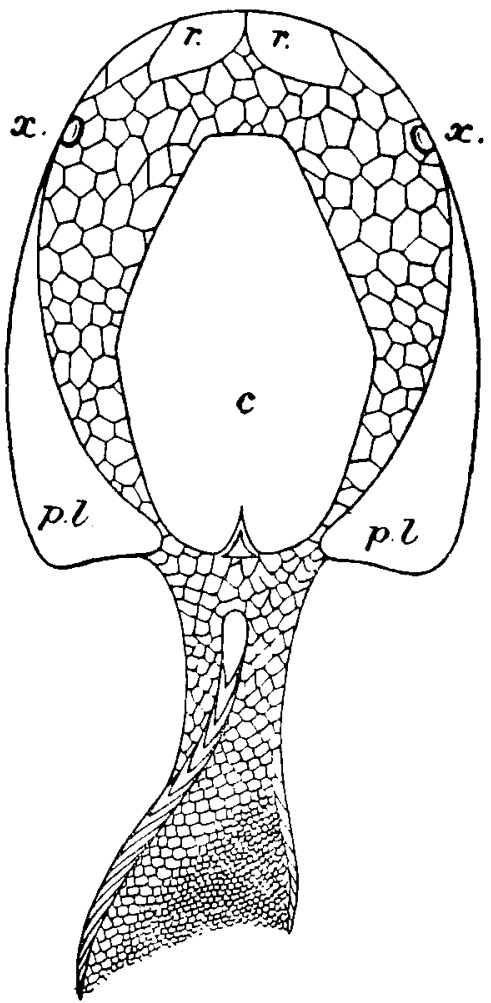

FiG. 5.-Drepanaspis Gmündenensis, Schlüter; restored outline of the dorsal aspect, the surface ornament omitted, and the tail twisted round so as to show the caudal fin in profile; $c$., central plate ; p.l., postero-lateral plates ; r., rostral plates ; $x$., orbits?

part forms a broad oblong carapace, rounded in front, abruptly truncated behind, where there is on each side a prominent though rounded angle. From the middle third of the transverse posterior margin the tail arises. The carapace consists of numerous bony plates, large and small. In the centre there is a large median dorsal plate (c) of a somewhat ovate-hexagonal contour, the anterior margin being short and somewhat straight; the posterior is more rounded, and is also acutely notched in the middle. The two postero-lateral angles are formed each by a large, narrow, triangular falciform plate $(p . l$.$) , which narrows to a very acute point more than half-way to the front of the$ carapace. The rest of the space is covered by a multitude of small polygonal plates, mostly hexagonal in contour, but the anterior margin itself is generally formed by a 
few plates of a larger size, which we may term rostral $(r$.$) . Lastly, on each lateral$ margin, a little way in front of the termination of the postero-lateral plate, may be seen a small rounded depression $(x$.$) which may represent an orbit, though in one case I see$ on its floor a portion of bone sculptured like the rest of the plate, but this may be $\dot{d}$ ue to some accidental displacement. This depression or cavity is of such constant occurrence that it must mean something.

On the ventral surface there is likewise a large oblong central or median ventral plate, but its posterior notch is larger, and its direction is continued forward for a little distance by a slight elevation or fold of the surface-hence, when detached, the plate can always be readily distinguished from the corresponding one on the back. The postero-iateral angles and margins are formed by the same plates $(p . l$.$) , which we saw$ on the dorsal surface, but a much narrower area of each is exposed. There are also a few broad plates at the anterior margin, the rest of the surface being filled in by small polygonal ones, exactly as on the dorsal aspect of the carapace.

All the plates of the carapace, both above and below, are ornamented by tolerably closely-set stellate tubercles. There is no trace of jaws or of teeth, but as it is impossible to conceive of the absence of a mouth, we must conclude that it was placed exactly at the anterior margin.

The tail is rather shorter than the carapace, and is covered with tuberculated quadrangular scales, which, becoming finer and smaller, are continued on the caudal fin, which is heterocercal but scarcely bilobate. But in addition to those lateral scales, we have, running along both upper and lower margins of the tail and caudal fin, a series of stout elongated imbricating "fulcral scales," those of the dorsal series being the longer. No trace of any other fins is to be seen, nor do we find any remains of internal skeleton.

After this brief description of the leading points in the structure of Drepanaspis, it is impossible even in the absence of evidence as to the microscopic structure of its hard parts, to avoid the conclusion that it is related to the Cœlolepidæ-in fact, that it forms an onward stage in the evolution of a common series to which the last-named family belongs.

We cannot fail to recognise the general resemblance in form-the broad and depressed anterior portion, rounded in front and truncated behind; the want of jaws and teeth; the slender tail with heterocercal caudal fin. But whereas the minute shagreen-scales of Thelodus have in Ateleaspis coalesced into polygonal tesseræ in front and rhombic scales behind, in Drepanaspis we have, added to the rhombic scales of the tail, well-developed fulcra, and as to the anterior part, we find that it is now covered by a regular carapace, into which enter not merely a multitude of small polygonal plates, but also several large ones, among which the great median dorsal and ventral plates and the falciform plates at the postero-lateral angles are conspicuous. Then, if the posterolateral lappet-like projections of the body of Thelodus and Lanarkia represent lateral fin-flaps, as I believe them to do, we find these parts in Drepanaspis, though still preserving the same general contour, rendered utterly functionless as fins by being enclosed 
in unyielding bony plates. In fact, the shark-like Cololepidæ seem to have specialised themselves into a form, which in former days would certainly have been called a veritable "Placoderm."

But if Drepanaspis points backwards to the Cololepidæ, it also points forwards to the Pteraspidæ, but the consideration of this question I shall defer till we come to treat of the last-named group itself. But before doing so we must look into the question of the affinities of the Psammosteidæ, a family upon whose hitherto somewhat doubtful position the structure of Drepanaspis throws an unexpected light.

\section{The Psammosteid 4 .}

The plates known as Psammosteus (Agassiz), which occur usually in a very fragmentary condition in the Deronian (Old Red Sandstone) rocks of Great Britain and Russia, have long been a puzzle to palæontologists. By AGAssiz, to whom only small fragments were known, Psammosteus was classed as a "Coelacanth" (ii. p. 61); by Trautschold, plates apparently belonging to the same genus were interpreted as swimming paddles of Coccosteus (xxxvii., Pl. VI., Pl. VII., fig. 2); but the most prevalent opinion at present is that these remains are elasmobranch in their nature, and belonged to some extinct group of "armoured sharks."

The remains of Psammosteus consist in the first place of large oblong plates, gently hollowed in boat-like fashion, obtusely pointed at one extremity (anterior), and truncated or obtusely notched at the other. Internally these plates are smooth, externally they are covered with minute closely-set tubercles, which are brilliantly ganoid and have beautifully crimped edges. In many instances these tubercles are arranged in polygonal areas, which in worn specimens are often removed, leaving shallow polygonal depressions behind, so as to give the surface of the plate something of a honeycombed appearance.

The inner layer of these plates is formed by a dense laminated substance perforated by vessels; the middle one is thicker, and shows a close network of vascular canals, the intermediate substance displaying numerous minute tubules, so that, as AGASSIZ already remarked, it appears more related to dentine than to bone. The outer layer consists of the tubercles themselves, which show a radiating arrangement of dentine tubules precisely similar to those figured by RоноN in the scales of Thelodus (xxviii. p. 33), while the external resemblance of these tubercles to certain Thelodus scales, especially to those of Thelodus Pagei from the Forfarshire Old Red (xxxvi. fig. 2), is obvious enough.

It seems, therefore, pretty clear that, as I have already remarked in my Extinct Vertebrata of the Moray Firth Area (xxxir. p. 262), the stellate tubercles of Psammosteus are shagreen-granules which have coalesced, and have also become united to a plate formed in a deeper layer of the skin. Here an analogy seems to be afforded by the condition of the dermal covering in Ateleaspis, on the anterior part of which we have also reason to believe that minute scales have run together into polygonal 
plates, which, small as they are, remind us strongly of the polygonal areas so often seen on the surface of the plates of Psammosteus.

It need scarcely be added that the large median dorsal and ventral plates of Drepanaspis and the oblong boat-like shields of Psammosteus mutually remind us of each other, and though the former never show any polygonal areas, the smaller plates with which they are surrounded are eminently suggestive of these areas as they occur in Psammosteus paradoxus, Agassiz, and Ps. Taylori, Traq.

There are, however, two other forms of plates often found associated with the large oblong ones above referred to, the structure and external sculpture of which lead us to refer them also to Psammosteus. Of these we have first certain flattened and somewhat falciform pieces, pointed and often worn at one extremity, and having towards that extremity the characteristic Psammosteus-ornament, which, however, covers more of the surface on one side than on the other. A fragment of one of these bodies was tigured by PANDER (xxii. Pl. VII. fig. 22) as an "Ichthyodorulite." From their want of bilateral symmetry, they must have occupied a lateral position, and they were indeed, as already remarked, figured and described by TRAUTSCHOLD as the paddles of a species of Coccosteus. Relying on the microscopic structure of these plates or "ichthyodorulites," which, as described by PANDER, consists of true dentine without any bone lacunæ, I referred them in 1890 (xxxiii. p. 134) to the category of "Selachian Appendages," noting also the certain amount of resemblance which they bear to the peculiar carboniferous species known as Oracanthus. A year afterwards they were noticed by SmitH WoodWARD in the second volume of his Catalogue (xxxviii. p. 126), and referred by him to Agassiz's Psammosteus meandrinus; and again, in 1895, in his Problem of the Primceval Sharks, he compares those bodies to Oracanthus, adding, as regards their position on the fish, that "they may have been arranged along the lower margin of the body, as in certain Acanthodian sharks (e.g., Climatius), or the animal may have had only a single pair of these spines at the back of the head, as described by Dr TRAQUAIR in Oracanthus." The second supposition is more feasible than the first, and I rather think that the "ichthyodorulites" in question were backwardly directed developments of plates corresponding to the postero-laterals of Drepanaspis.

The third form of Psammosteus-plate, of which Pander (xxii. Pl. VII. fig. 16) figured an example as possibly a caudal scale or spine of Asterolepis, is comparatively small in size, bilaterally symmetrical, oblong, bluntly pointed at one extremity, and sculptured externally with the usual shagreen-like tuberculation.

Mr Smith Woodward remarks (xxxvii. p. 39), concerning these bodies, that they are shaped much like the rostrum of Pteraspis, but in my mind there is not the slightest doubt that they are ridge-scales of the tail, similar to those which are to be found in situ in Drepanaspis.

It is now pretty clear that Psammosteus is closely allied to Drepanaspis, - so closely that it may be a question as to whether there is any need for family distinction. I think, however, that it is better for the present to keep them in separate families until 
the microscopic structure of the hard parts of Drepanaspis can be investigated and more also is known regarding the configuration of Psammosteus and the arrangement of its plates.

But as regards Oracanthus, I must now abandon all idea of its being related to Psammosteus, retaining it indeed as a veritable Selachian. Certainly it is so, if the carboniferous fish which I named and described as Oracanthus armigerus (xxxii. p. 86) has anything at all to do with the genus in which I placed it. The position of the spines of $O$. armigerus is at the back of the head, one on each side, like the cornua of Cephalaspis, but the dentition is cochliodont, and the creature is evidently closely allied to Menaspis armata, Ewald, from the German Kupferschiefer.

Meanwhile the problem of the "armoured sharks" is, I think, solved, by our ceasing to consider them, properly speaking, as sharks at all, and transferring them to the Heterostraci. This is in accordance with views already expressed by $\operatorname{Dr}$ O. M. REIS of Munich, as we shall presently see.

\section{The Pteraspide.}

The Pteraspidæ, the only family which by common consent has hitherto been included in the Heterostraci of Lankester (Aspidorhini, RoHon), have, like the Psammosteidæ, no bone lacunæ in the substance of their dermal plates, but the middle layer, instead of consisting altogether of a dense reticulation of Haversian canals, forms in its lower part at least a stratum of polygonal or prismatic cavities, which is the cancellated layer. The outer layer consists of dentine, or kosmine, with fine arborescent tufts of minute tubules. The external sculpture consists of fine concentric and sub-parallel ridges and grooves, but the ridges, as Prof. Lankester observes, "are usually crenated at the margins, and give the notion in some species of a linear series of minute tubercles fused together." Further on he also observes:- "Indeed each of the sections of the ridges recalls very strongly the structure of a tooth or of a dermal defence of a placoid fish" (xiv. pp. 11-12).

In fact the microscopic appearance of the ridges when seen cut in transverse section at once recalls the structure of the tubercles of Psammosteus, or of the crowns of the scales of Thelodus, and I have no doubt that we have the explanation of their origin in the idea of the fusion of Coelolepid dermal tubercles or shagreen-bodies in linear order. That these ridges originated by the fusion of "placoid" scales of some sort at least was strongly advocated by RoHON in the first part of his monograph on the Upper Silurian Fishes of Oesel (xxvii. p. 75), where he says:-

"Ich muss Prof. Ray Lankester beistimmen, wenn er in dem Bau der äusseren oder Leistenschicht des Pteraspis-Schildes die Structur der Placoidschuppen erblickt und diese Schicht aus demselben Grunde auf die Placoidschuppen zurückführt. Wird an dieser vollkommen richtigen. Anschauung festgehalten, so ist die Existenz der Knochenzellen wie ganz treffend Ray Lankester hervorhebt, für die Wirbelthiernatur 
des Pteraspis vollständig überflüssig, dass aber die leistenartigen Erbabenheiten der Schildoberfläche vom Pteraspis aus der Verschmelzung zahlreicher Placoidschuppen hervorgegangen sind davon kann man sich ohne Rücksicht auf den histiologischen Bau auch bei macroscopischer Betrachtung überzeugen."

However, in the second part of his researches on the Silurian Fishes of Oesel (xxviii. p. 105), the same author proposes an alternative and opposite view of the casenamely, that the ridges of the Pteraspidx might have been the most primitive condition of the dermal skeleton of the Vertebrata, out of which, by differentiation, the dermal denticles (placoid scales) of the Selachii, as well as their modifications in the Ganoids, Teleostei, \&c., have arisen. Again, to quote his words :-

"Indessen könnte ebensogut die gegentheilige Ansicht gelten, d. h. die Streifchen und Plättchen der Pteraspiden könnten den ursprünglichen Zustand des Hautskelets der Vertebraten bilden, so dass also aus den Streifen und Plättchen der Pteraspiden durch Differenzirung die Hautzähnchen (Placoidschuppen) der Selachier gleichwie die entsprechenden Modificationen bei deren Descendenten (Ganoiden, Teleostiern, Amphibien, \&c.), entstanden wären. Demgemäss würden die länglichen Streifen, Leistchen oder Plättchen der Pteraspiden als die auf der niedersten Entwickelungstufe befindlichen Hartgebilde an der Körperoberfläche bei den Vertebraten darbieten."

It seems to me that, on this occasion at least, second thoughts have not proved the best, for to suppose that the ridges of so specialised a structure as a dermal plate of Pteraspis are likely to be more archæic in character than the simple shagreen-bodies of the Cololepidæ formed round a simple papilla, seems to me to be indeed rather like putting the cart before the horse. But Prof. RoBon does not seem to insist very strongly on his new theory, as may be seen from the remarks which immediately follow his enunciation of it. It is, moreover, interesting to see that in comparing the microscopic structure of the ridges of Pteraspis with that of placoid scales, he makes in this paper special reference to the Cololepidæ:-“da die Streifen und Plättchen der Pteraspiden die gleiche microscopische Structur wie die den recenten Placoidschuppen gegenüber als einfachere und ältere Hautzähnchen erkannten Cololepiden aufweisen" (ib., p. 106).

Much remains still to be learned about the Pteraspidæ, but the configuration and structure of the carapace which covers the head and anterior part of the body in the type genus Pteraspis is pretty well known through the researches of HuxLEY, Lankester, Alth, and others.

The head and anterior part of the body of Pteraspis is enclosed in a carapace, the dorsal part of which shows evidence of having been originally composed of at least seven distinct plates, though in these fossils, as we usually find them, the pieces are not actually separate. Text-figure 6 shows the arrangement of the parts of the dorsal surface of the carapace, while the accompanying text-figure 7 is a restoration of the entire fish slightly altered from the figure given by SMIrH Woodward in the second volume of his Catalogue, p. 161. 
The greater part of the carapace, as seen from above, is composed of the oblong median dorsal plate (D), which is slightly bilobate in front, while posteriorly it presents a narrow deep notch, into which fits the dorsal spine (S). In front of the median plate is the anteriorly-pointed rostral one $(\mathrm{R})$; while fitting into the angle between these two, on each side, is the triangular orbital plate $(0)$, each of which shows a small opening, just on the edge of the carapace, and supposed to be for the eye. Behind this is the cornual plate (C), one on each side of the median dorsal, and forming a right and left prominent postero-lateral angle. Each of these plates, also visible on the ventral aspect of the fish, forms the sharp lateral edge of the carapace behind the orbital region, and is perforated near its hinder angle by a pretty large oblique opening (B), usually supposed to be branchial in its function. Lastly it is to be mentioned that on the inner aspect of the carapace, just between the median dorsal and rostral plates is a small but very distinct round median pit, which was probably supported by a minute eighth or pineal plate. (See Lankester, xiv. p. 28 ; Alth, iii. p. 43.)

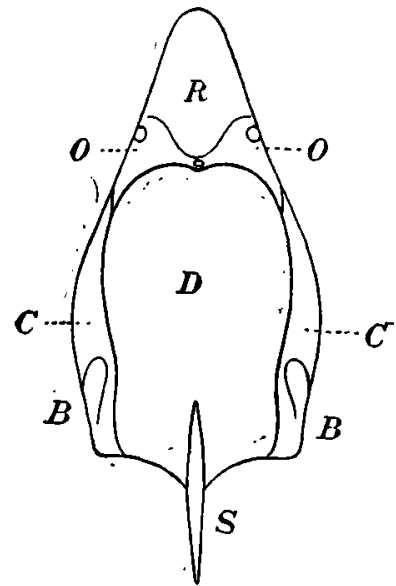

FIG. 6.

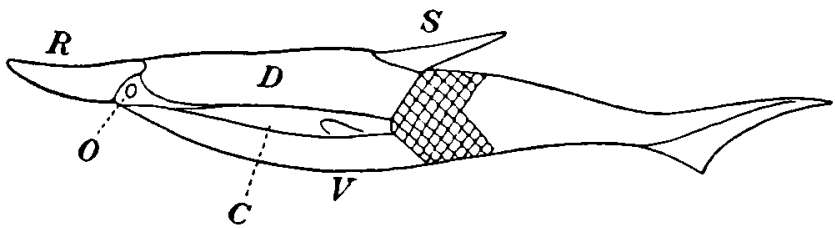

Fis 7 .

Fig. 6, Diagram of the dorsal surface of the carapace of Pteraspis rostrata, from specimens in the British Museum. Fig. 7, lestored outline of the same fish seen from the side, slightly altered from a figure by Mr A. SMith Woodward. (D) Median dorsal plate; (S) Spine ; (C) Cornual plate; (O) Orbital plate ; (R) Rostrum ; (V) Ventral plate ; (B) Branchial opening. The posterior caudal scales are here omitted.

On the ventral surface (text-figure 7 ) is a large oblong median ventral plate (V), once described by Lankester as a distinct genus (Scaphaspis). The mouth must have been placed between the anterior margin of this plate and the posterior-rentral aspect of the rostrum.

It is impossible to compare this carapace with that of Drepanaspis (text-figure 5) without being struck by the general resemblance in the arrangement of the parts in both. In each there is on the dorsal surface a great oblong median plate notched behind, although there is no dorsal spine in Drepanaspis. The cornual plates of Pteraspis are represented by the postero-laterals of Drepanaspis, though in the latter genus no branchial opening is observable, at least in the position in which it

VOL. XXXIX. PART III. (No. 32). 
occurs in the former. The position of the orbits in Pteraspis on the edges of the anterior part of the carapace is relatively identical with that of the rounded depressions which I take to represent orbits in Drepanaspis. But there is no distinct specialised rostral plate in Drepanaspis, and the mass of small polygonal ones which surround the median plate have altogether disappeared in the Pteraspidæ.

Then again on the under surface of Drepanaspis there is a great median ventral plate, comparable to that of Pteraspis, though it is again surrounded by small ones like the dorsal one above.

So far as the arrangement of the plates of the carapace is concerncd, Pteraspis then suggests to us a specialised form of Drepanaspis.

The tail of Pteraspis is only known by three fragments, two of which were figured by Lankester (xiv., Pl. V., figs. 1, 3, 5, 8). One of these, from Cradley, Herefordshire (tab. cit., figs. 3 and 8), and now in the British Museum, is the basis of the restored squamous portion of the tail in LANKESTER and SMITH WoodWARD's reconstructions, and shows that this part was covered by somewhat imbricating rhombic scales. The second specimen, from the Powrie collection, and now in the Edinburgh Museum of Science and Art, is from the Bridge of Allan, where it occurred along with carapaces of Pteraspis Mitchelli, Powrie. To this specimen LANkester did not devote much space in his monograph, merely remarking (op. cit., p. 33), under Ptercspis Mitchelli, that "a few rhomboidal scales also obtained by Mr Powrie from this locality (Pl. V., fig. 1) probably belong to this or another species."

This patch of scales is, however, worthy of careful examination. As may be seen in Prof. Lankester's figure, it is a narrow band two inches in length by three-eighths in breadth, starting apparently from a larger mass, of which the remains are, however, no more than barely indicated. It is to be noted that the scales, quadrangular in form, become smaller towards what was apparently the distal extremity of the patch, while on one aspect there is something to be seen which Prof. LANKESTER had apparently overlooked-namely, some undoubted remains or traces of a fin-membrane covered by minute scales. I have therefore no doubt that this specimen is the remains of the upper lobe of a heterocercal Pteraspidian tail, and belonging in all probability to Pt. Mitchelli.

The third example is from the Lower Devonian of the Rhine country, and has been briefly alluded to by Prof. Schlüter (xxx. p. 125) under the name of Scaphaspis Bonnensis. The specimen is in the Geological Museum of the University of Bonn, where I have on two occasions had the opportunity of looking at it for a few moments, but I did not find that it showed anything more than the fact already knownnamely, that the Pteraspidian tail was provided with a covering of small scales.

The tail, then, of Pteraspis, so far as we know it, is also in accordance with that of Drepanaspis, and the conclusion seems to me to be certainly warranted-namely, that the Pteraspidæ are related to the Drepanaspidæ as more highly specialised forms of one common series. 
GEOLOGICAL SURVEY IN SILURIAN ROCKS OF SOUTH OF SCOTLAND. 853

. No doubt this conclusion would be invalidated if it were proved that any Pteraspidian possessed distinct Crossopterygian-like paired fins, like those indicated by Claypole in his "attempted restoration" of Palceaspis Americana (v. p. 560). But this is far from being the case. Judging from Prof. Claypole's sketches it does seem to me that the resemblance of the objects in question to Crossopterygian fins is rather superficial, and the author himself admits that "no specimen (as aforesaid) shows this organ ju position." Prof. JAEkEL of Berlin (xiii. p. 467) has expressed the opinion that the supposed fins are isolated portions of the dermal armature, and probably scales.* A different view, but equally decisive against these objects being fins, has been put forward by Dr BASHFord Dean of New York (viii. p. 71, footnote) in the following words :-

"The presence of paired fins in Palæaspis, as determined by Claypole, has not been confirmed. The present writer, to whom the type specimens were kindly shown by their describer, must regard these structures as elasmobrauchian (Chimæroid?) spines, in crushed condition, accidentally associated with the head region of the fossil."

So with due apologies to Prof. Clay pole, we cannot accept the occurrence of distinct paired fins in the Pteraspidæ as an ascertained fact.

\section{The Heterostraci.}

If the Pteraspidæ are related to the Drepanaspidæ, then it follows, by the same line of reasoning, that they are also related to the Psammosteidæ, and finally to the Coelolepidæ. The conception of the Heterostraci is, therefore, widened by the addition of three families, showing almost every gradation from the shark-like Thelodus, with its shagreen-covered skin and lappet-like pectoral fin-folds, to Pteraspis, which, with its box-like carapace, composed of a limited number of sculptured plates, its scaly tail, presents us with as good a type of the so-called "Placoderm" or "Panzerfisch" as any palæozoic creature which has ever been brought under that designation.

What characters are now to be considered as common to the menbers of this order?

They all have this in common, that the microscopic structure of the dermal hard parts (unknown, however, in Drepanaspida) is either that of dentine, or at least of a substance partaking more of the nature of dentine than of bone. $t$ In none has any internal skeleton been found, or any distinct jaws or teeth. The eyes, where their position has been observed, are situated on the outer edge on each side of the anterior part of the carapace. Those whose external form is sufficiently known have all a strongly heterocercal caudal, but no other median fins.

\footnotetext{
* "Nach Alledem glaube ich mit voller Sicherheit annehmen zu müssen, dass die für Flossen gehaltenen Skeletstücke nichts anderes als isolirte Hautpanzertheile und zwar Schuppen des Fisches sind."

+ Scнmidr (xxxi. p. 16-17) described and figured the occurrence of lacunae in the ridges of the Pteraspis-shield, but this was denied by LaN KESTER, and finally disproved by RоHоN (xxvii. p. 74-75). As regards Psammosteus the last named author maintains the occurrence, in the lowest layer of the shield of simple spindle-shaped bone cells which, however, "weisen fast gar keine Primitivröhrchen auf" (xxviii. p. 70-71). These I have yet not seen, but Prof. ROEON says they are only visible in especially well preserved examples.
} 
Specialisation from the most primitive form (Lanarkia) to the most specialised (Pteraspidæ) has been accompanied by :-

1. Fusion of the spinelets (Lanarkia) or shagreen grains (Thelodus) into plates, scutes, and rhombic scales, supported by hard matter, developed in a deeper layer of. the skin.

2. Alterations in the pectoral fin-flaps, which becoming covered up by the posterolateral plates in Drepanaspis, are finally no longer recognisable in the Pteraspidæ.

- Now, if it be admitted that the Coelolepidæ are of Elasmobranch origin-they have hitherto, from the structure of their shagreen-bodies, been looked upon as actual sharks -then it follows, if my views are correct, that the entire group of Heterostraci owes its origin to an Elasmobranch source. This idea has been already foreshadowed, at least as regards the Pteraspidæ and Psammosteidæ, by Dr O. M. ReIs of Munich, in his remark-“ dass Pteraspiden und Psammosteiden sehr nahe mit einander verwandt eine einheitliche Degenerationsgruppe der Elasmobranchier bilden, für welche ich den Namen Psammacanthiden vorschlage" (xxv. p. 64). Again, in another and later publication, he says- "Pteraspiden und Psammosteiden gehören zusammen auf Grund der microscopischen Structur, welche zwar placoid ist, aber die Eigenheit zeigt, dass das Dentin auf die ausserste Schicht beschränkt wird; es ist dies aber eine Structurdifferenzirung zu gross plattiger und massiver Stachel- und Hautplattenentfaltung deren Beginn auch bei den Holocephalenzähnen zeigt" (xxvi. pp. 213-214). However, he does not seem to have suspected any special aftinity between his Psammacanthiden (Heterostraci) and the Cololepidæ, for, on a previous page of the same paper (p. 211), he adheres to the old view as to the correlation of Thelodus and Onchus,_- "mit mehreren andern Forschern halte auch ich es für sehr wahrscheinlich, dem die zusammenvorkommenden Thelodus;Schuppen und. Onchus-Flossenstachel einer und derselben Haifischgattung angehören."

It follows now that, if the views which I have here supported as to the derivation of the Heterostraci be accepted, two other theories which have been propounded regarding their affinities must fall to the ground.

The first is that originated by the late Prof. E. D. Cope, who, placing the Pteraspids, Cephalaspids, and afterwards also the Asterolepids, * in one sub-class of " Ostracodermi," associated this sub-class with the Marsipobranchii or Cyclostomes (Lampreys and Hags) in one class of Agnatha, apart altogether with the Pisces or Fishes. This idea, founded on the apparent alssence of lower jaw and shoulder-girdle in the Ostracodermi, has been accepted by SMith Woodward in his obituary notice of CoPe (xl. p. 379), as well as in his recently published Manual of Vertebrate Palcoontology (xli. p. 1). It also appears in Dr Bashford Dean's Fishes, Living and Fossil, where, in his table of Classification of Fishes, he boldly adopts, in place of "Agnatha," the term " Marsipobranchii," previously used only for the Lampreys and Hagfishes themselves. In the table of

* The Asterolepids or "Antiarcha" were, however, first added to the Ostracodermi by Mr SMITH WooDWARD (xxxviii. p. 17). 
distribution of fishes in geological time, however, which is given on the next page of the same work, though still placing the Pteraspids, Cephalaspids, and Pterichthyids under the Marsipobranchii, he qualifies the position by the judicious use of points of interrogation. A few pages further on (p. 66), speaking of the Ostracodermi, including the Pteraspidæ, he indicates his opinion that they "are in no way closely connected with the ancient shark types."

For this doctrine of an affinity between the Marsipobranchii and any of the groups reckoned to the "Ostracodermi," I myself never could perceive any real justification, and I consequently found myself quite in agreement with the opinions expressed by Prof. LANKESTER in the short paper (xvi.) which he wrote on the opposite side of the question. Prof. LaNkester lays principal stress on the entire absence of any proof that the Ostracodermi were monorhinal like the Lampreys and Hags. I would go further and ask, Where is the evidence that they were really "agnathous"? These fossils nerer show any trace of endo-skeleton at all-it must have been entirely cartilaginous-so that it would be just as reasonable to affirm that they had no chondrocranium. Again, it is by no means so certain that the term "Agnatha," if taken to indicate a primitive deficiency of the mandible or mandibular arch, can properly be applied even to the Cyclostomes, for though the distinguished embryologist F. M. BaLfour believed that their ancestors never had lower jaws, and that they themselves are the "remnants of a primitive and prægnathostomatous group," * the opinions of those who consider these creatures to be degenerates from originally gnathostomatous forms cannot be entirely overlooked (see Howes, x.). HuxLEY (xi.), and following him, Howes (op. cit.) have even maintained that, in the cartilaginous framework of the Marsipobranch head, elements are present which represent parts at least of the mandibular arch in the true Gnathostomata, $\dagger$ though the latter author, from other developmental reasons, emphasises the enormity of the gap which lies between the Marsipobranchii and the other and higher Vertebrata.

It is not, however, necessary to enter further into the agnathous question, if the palæontological facts described in this report indicate that the Pteraspidæ, Drepanaspidæ, and Psammosteidæ, are derivable from the Cœlolepidæ, and that the latter are of Elasmobranch origin.

For the same reason we need not enter into any very detailed discussion of the second theory to which I have referred-namely, that of Prof. W. Patien, who seems to be endeavouring to revive, on a scientific basis, what we have long considered to be

* Comparative Embryology, London, 1881, vol. ii. p. 69.

+ HoXLEY says regarding Petromyzon (op. cit., p. 427):- " The posterior lateral cartilages are directly connected with that end of the suborbital arch, which answers to the articular end of the suspensorium in the frog, and in their position exaggerate the peculiar arrangement of the tadpole's meckelian cartilage. That they are parts of the mandibular arch I believe to be certain, but in the absence of any knowledge of their mode of development, I leave the question as to their exact homology open." This view is supported by Howes, who also finds a representative of the mandible in the prepalatine cartilage of Myxine, remarking,- "In its relationships to the superficial branches of the trigeminal nerve, this ' prepalatine' closely corresponds with that which HoXLEY claimed as MECKEL's cartilage in the Lamprey, and with that I hold it to be homologous notwithstanding Parker's view to the contrary " (op. cit., p. 133). 
obsolete guesses as to a true zoological (we should now call it a genetic) affinity between the ancient plated fishes of the Silurian and Devonian epochs and Arthropoda. It will be remembered that nearly ten years ago Prof. PatTen compared the sutures and other markings on the head of a Trilobite with those on the cranial shields of Pterichthys and Bothriolepis, though unsuccessfully, as he had unfortunately taken his figures from old restorations, in which sutures and sensory grooves were confounded. He now (xxii.) finds a strange similarity between the microscopic characters of certain chitinous trabecular structures "underlying the external chitinous covering of the body" of Limulus and those of the plates of the carapace of Pteraspis. These trabeculæ contain in their centres, or cores, minute cavities, which he compares to bone-lacunæ; and each of these sends off a delicate tubule or canaliculus vertically to the surface. "When the chitinous network forms a rather thin layer, as in the eye region and elsewhere on the thoracic shield, the innermost trabeculæ unite to form a nearly continuous layer, perforated by pores, that lead into the irregular sinuses above them." This he compares with the basal layer of Pteraspis, while the layer above, "crossed in various directions by the chitinous trabeculæ containing the lacunæ," he divides into two, of which the lower corresponds to the cancellated, the upper to the reticulated layer in the same fish-plates. Lastly, the "thick outer cuticula" he compares to the outer layer of Pteraspis, the most superficial and colourless stratum representing the ganoine, while he evidently looks upon the deeper part which is permeated by "innumerable canaliculæ (pore canals of authors)" as the dentine or kosmine layer. He concludes the descriptive part of his paper by stating that "the only animals known to show such an exoskeleton as Limulus are some of the remarkable fishes known as Cephalaspidæ," under which designation he includes also the Pteraspidæ.

I have not myself examined the dermal structure of Limulus microscopically, but I have read Prof. Patten's paper very carefully, and must own that I fail to see, more especially in his figures, such a correspondence between the structure described in Limulus and the structure of the plates of Pteraspis as would warrant us in supposing that the two forms were "genetically related." Pteraspis has no bone-lacunæ, but here Prof. PATten calls in the aid of Cephalaspis, in which, however, the lacunæ are quite different from the appearances figured as such in Limulus. Nor do I see anything in Prof. Patten's figures having the slightest resemblance to the dentine or kosmine layer of Pteraspis. Prof. Patten says-." As to its peculiar surface ornamentation, the shield of Pteraspis is exceptional among the Cephalaspidæ, and need not at present be considered." But it is here where the gist of the matter comes in. The crenulated ridges of Pteraspis obviously consist of shagreen-bodies, like those of Thelodus, but run together in lines, and the derivation of the family from an Elasmobranch source is indicated in a way, which superficial resemblances to other groups cannot in any way touch.

To sum up, then, I must consider the Heterostraci to be of Elasmobranch deriva- 
tion, and would include under them the following families, in their order of specialisation :-Coelolepida, Psammosteida, Drepanaspida, and Pteraspida.

\section{Heterostraci and Osteostract.}

Although the classification of the Orders Heterostraci (Pteraspids), Osteostraci (Cephalaspids), and Antiarcha (Asterolepids), together in one great division or class of "Ostracodermi," as adopted by CoPE and SMiTh WoodwaRD, is, in the present state of knowledge, very convenient, and has for that reason been used by myself, it has not, howerer, gained universal assent. REIS protests against the union of the Pteraspids and Cephalaspids as "unbegründet" and "unbeilvoll," while Prof. LANKESTER, who thirty years ago treated them in his classical monograph as "sections" of one group, * has emphasised another view of the matter in the short paper in Natural Science to which I have already referred (xv. p. 46), and where he says"There is absolutely no reason for regarding Cephalaspis as allied to Pteraspis beyond that the two genera occur in the same rocks, and still less for concluding that either has any connection with Pterichthys."

I must nevertheless hold that the configuration and structure of the remarkable, though imperfectly known genus Ateleaspis does seem to indicate that there is, after all, an actual connection between the two groups. So far as the external form of Ateleaspis, shown in the specimen represented in Pl. IV. fig. 6, is concerned, the resemblance to Thelodus is so striking, that the idea of a genetic connection between them is well-nigh unavoidable, and in truth I placed it at first immediately after the Coelolepidæ in the order Heterostraci, even although certain misgivings were aroused in my mind by the crescentic markings (see text fig. 2) which seemed to point to the presence of orbits on the top of the head as in Cephalospis. But when I succeeded in obtaining microscopic sections of the scales, and saw that the indications of a Ceph $\alpha$ laspis-like position of the orbits were correlated with the presence of true bone lacunæ in the dermal hard parts, then I felt compelled to transfer Ateleaspis to the Osteostraci, though with a tolerably strong conviction that we have here an annectent form--in fact, a "missing link." Here, however, it must form the type of a very distinct family, characterised especially by the want of the pre- and post-orbital openings or markings of the Tremataspidæ and Cephalaspidæ, the acute lateral cornua of the latter being also absent. We do not know if the shield was flexible; at all events its composition, externally at least, out of a multitude of polygonal tuberculated plates gives it a resemblance to that of Cephalaspis as well as of Psammosleus. For though the apparent tessellation of the shield of Cephalaspis may be "deceptive," inasmuch as the tesseræ are not actually separate from each other, but take part in the formation of

\footnotetext{
* It must, however, not be forgotten that Prof. LankesTer in the concluding page of that monograph (xiv. p. 62), even then stated that "The Heterostraci are associated at present with the Osteostraci because they are found in the same beds, because they have, like Cephalaspis, a large head-shield, and because there is nothing else with which to associate them."
} 
one continuous structure in the forms with which we are acquainted, we are, I think, justified in supposing that they were originally distinct pieces.

If we now turn to the lappet-like expansions behind the head in the Cololepidæ and Ateleaspidæ, which I have interpreted as pectoral fins, we shall see that they bear a strong resemblance to the flap-like structures in Cephalaspis, which are organically continuous with the head shield, and placed immediately internal to the cornua and behind the head. It will be remembered that these were originally described by LANkESTER as pectoral fins (xiv. p. 41), though SMITH WoodwarD designates them with a query as opercula (xxxvi. p. 176). If the homology of these parts is accepted, it follows that if they represent pectoral fins in Thelodus, as such they must also be looked upon in Cephalaspis, and consequently LANKeSTER was right in his original interpretation.

I am therefore meanwhile of opinion, that the association of Heterostraci and Osteostraci in one great subclass of Ostracodermi is not a mere delusion founded on the occurrence together, geologically, of their fossil remains, and on the presence in both of a cephalic shield, but is supported by the facts brought forward in this paper. The position of the Asterolepidæ does not come within the scope of the present observations.

But unless the Ostracodermi are to be maintained, though it might be only as a "lumber room," we have no place in the system for the two remarkable genera of fishes, with the consideration of which I may now conclude this report.

The Anaspida.

I have placed the genera Birkenia and Lasanius together in one family, because both possess a fusiform body with bluntly rounded head, a bilobate heterocercal tail, and a median row of aculeated scutes on the ventral margin. In neither do we find any jaws, teeth, paired fins, shoulder-girdle, or ossified internal skeleton.

Birkenia has the head and body completely covered with scutes. Lasanius, though nearly naked, has a row of median ventral aculeated plates resembling those of Birkenia, and the only other dermal hard parts which it possesses-the parallel rods behind the head-are directed, for the greater part of their extent, downwards and forwards like the elongated lateral scutes of Birkenia.

So I am inclined to look upon Lasanius as standing much in the same relation to Birkenia as the nearly naked Phanerosteon does to the other genera of Palæoniscidæ, whose bodies are covered with osseous scales. Lasanius seems to bave lost its scutes, and is consequently a more specialised form.

As to Birkenia itself, its heterocercal tail, its small posteriorly situated dorsal fin, and its narrow tuberculated body-scutes, do remind us strangely of Cephalaspis, in which genus it must also be noted that the lateral scutes, if not directed actually downwards and forwards like those of the former fish, are at least vertical, and do not pass obliquely backwards like the bands of scales on the sides of the ordinary "Ganoids."

The under surface of the head of Cephalaspis is as yet imperfectly known, and no 
branchial openings have as yet been seen or described in that genus. But if we consider the row of eight openings, apparently branchial, which in Birkenia are arranged in an oblique line on the side, at the junction of head and body (see text figure 3), we are struck by the very interesting fact that RoHON has already figured two rows, right and left, of similar openings on the ventral surface of the Osteostracan genus Tremataspis (xxvii. p. 70 and xxix. p. 8), though the number of openings here is only six on each side. Now, in Tremataspis the head is broad and depressed, while in Birkenia the creature, as it is always found lying on its side, must have been more laterally compressed, and consequently the position of the branchial openings must have been in the two genera relatively as in the skate and in the shark.

For these reasons I have often felt inclined to refer the Birkeniidæ to the Osteostraci, but there are two serious difficulties in the way of this idea. The first is the absence of the cranial buckler with orbits on the top, which is so prominent a feature in all known Osteostraci. The second difficulty is the utter absence of any microscopic proof, as the apparent substance of the scutes of Birkenia, as preserved in the schists of such localities as Birkenhead Burn, shows in sections under the microscope absolutely no structure whatever, except a very faint fibrillation or striation.

But whatever may be the position which increased knowledge may afterwards assign to Birkenia and Lasanius, for the present they are best placed in an Order by themselves, for which, I repeat, no place can be found in the system unless we admit it to the "Ostracodermi."

\section{Conclusion.}

The fossil fishes from the Silurian rocks of the South of Scotland, described in the preceding pages, constitute eight species, which are all new to science. They may be arranged in five genera, four of which are also new; the remaining one, Thelodus, having been named by AGASsIz in 1831 from detached szales occurring in the Ludlow Bone Bed. The following classification of the species has been adopted :--

Sub-class-OSTRACODERMI.

$$
\begin{aligned}
& \text { Order-Heterostraci. } \\
& \text { Family-Cololepidce. }
\end{aligned}
$$

1. Thelodus Scoticus, Traq.,-Ludlow and Downtonian horizons.

2. " planus, Traq.,-Ludlow.

3. Lanarkia horrida, Traq.,-Downtonian.

4. " spinosa, Traq.,-Downtonian.

5. " spinulosa, Traq.,-Downtonian.

VOL. XXXIX. PART III. (NO. 32). 


\section{Order-Osteostraci.}

Family-Ateleaspida.

6. Ateleaspis tessellata, Traq.,-Downtonian.

$$
\text { Order-ANASPIDA. }
$$

$$
\text { Family-Birkeniidce. }
$$

7. Birlienia elegans, Traq.,-Ludlow and Downtonian.

8. Lasanius problematicus, Traq.,-Downtonian.

And whether the views which I have expressed regarding the phylogeny and classification of these and allied forms be adopted or not by subsequent writers, it cannot, I think, be denied that these recent discoveries by the Geological Survey have opened out a new vista in the field of palæozoic ichthyology.

I must conclude by thanking the Director-General of the Geological Survey for his kindness in submitting this very important collection to me for description, and the officers of his staff for the friendly courtesy and readiness with which they afforded me every facility for its examination.

\section{LIST OF WORKS REFERRED TO.}

[The undernoted writings are referred to in the text by small Roman numerals.]

1. Agassiz, L. - "Recherches sur les Poissons Fossiles." Neuchâtel, 1833-43. 1844.

2. Agassiz, L._" Monographie des Poissons fossiles du vieux Grès rouge." Neuchâtel and Soleure,

3. Altr, A. v.- "Ueber die palæozoischen Gebilde Podoliens und deren Versteinerungen," Abh. der. k. k. geolog. Reichsanst, Bd. vii. Heft 1. Wien, 1874.

4. Alth, A. v.— "Ueber die Zusammengehörigkeit der den Fischgattungen Pteraspis, Cyathaspis, und Scaphaspis zugeschriebenen Schilder," Beitr. Palceont. Oesterreich-Un!/arns, vol. v., 1886.

5. Cla prole, E. W.- "On the Structure of the American Pteraspidian, Palceaspis (Claypole): with Remarks on the Family," Qu. Journ. Geol. Soc., vol. xlviii., 1892, pp. 542-561. 849.877 .

6. Cope, E. D.- "Synopsis of the Families of Vertebrata," Americ. Naturalist, vol. xxiii., 1889, pp. 278-281

7. Cope, E. D.- "On the Phylogeny of the Vertebrata," Proc. Amer. Philos. Soc., vol. xxx., 1892, pp.

8. Dean, B.-“Fishes, Living and Fossil." New York, 1895.

9. Gürich, G.- "Ueber Placodermen und andere devonische Fischreste im Breslauer Mineralogischen Museum," Zeitschr. der cieutschen geol. Gesellschaft, vol. xliii., 1891, pp. 902-913.

10. Howes, G. B.- "On the Affinities, Inter-relationships, and Systematic Position of the Marsipobranchii," Trans. Biol. Soc. Liverpool, vol. vi. pp. 122-147.

11. Huxler, T. H.- "On the nature of the Craniofacial apparatus of Petromyzon," Journ. Anat. and Plyys., vol.x., 1876, pp. $412+429$. 
12. Hunter-Selkirk, J. R. S.- “Three Months' Tent Life among the Silurian Hills of Logan Water, Lesmahagow," Trans. Geol. Soc. Glasgow, vii. pt. 2, 1885, pp. 272.278.

13. JAEKEL, O.—"Referat uiber E. W. Claypole: On the structure of the American Pteraspidian," \&c. Neues Jahrbuch für Mineralogie, 1894, Bd. ii. pp. 466-7. 1870.

14. LankEster, E. Ray.- "Fossil Cephalaspidæ of Great Britain," Palæontographical Society, 1868 and

15. Lankester, E. RAY.- "On Holaspis sericeus and on the Relationship of the Fish-genera Pteraspis, Cyathaspis, and Scaphaspis," Geol. Mag., vol. x., 1873, pp. 241-245.

16. Lankester, E. RAY. - "The Taxonomic Position of the Pteraspidæ, Cephalaspidæ and Asterolepidae," Natural Science, vol. xi., 1897, pp. 45-47. (Answered by Mr Smith Woodward, ib., p. 144.)

17. M'Coy, F.- "On the supposed fish remains figured on Plate 4 of the 'Silurian System," Qu. Journ. Geol. Soc., ix., 1853, pp. 12-15.

18. M'Cor, F.- "A Systematic Description of the British Palæozoic Fossils in the Geological Museum of the University of Cambridge." London, 1851-55.

19. Murchison, R. I.- "The Silurian System," vol. i. London, 1839. Contains descriptions of fish remains, with figures, by L. Agassiz.

20. Murchison, R. I.- "Siluria." London, 1854.

21. Pander, C. H._"Monographie der fossilen Fische des silurischen Systems des russisch-baltischen Gouvernements." St Petersburg, 1856.

22. PANder, C. H.- "Ueber die Placodermen des devonischen Systems." St Petersburg, 1857.

23. Patren, W.- "On Structures resembling dermal Bones in Limulus," Anat. Anzeiger., Bd. ix. No. 14, 1894, pp. 429-438.

24. Powrie, J.- "On the Earliest known Vestiges of Vertebrate Life; being a Description of the Fish Remains of the Old Red Sandstone of Forfarshire," Trans. Geol. Soc. Edin., vol. i., 1870, pp. 284-301.

25. REIS, O. M.—“Zur Kenntniss des Skelets der Acanthodinen," Geognostische Jahreshefte, vi., 1893.

26. Rers, O. M.- "Ueber Acanthodes Bronni, Agassiz," Morphologische Arbeiten herausgegeben von G. Schwalbe, vi.

27. Rohon, J. V.—“Dis obersilurischen Fische von Oesel. I. Theil. Thyestidæ und Tremataspidæ," Mem. Acad. des Sciences St. Petershourg (7), vol. xxxviii. No. 13, 1892.

28. Rоноn, J. V._"Die obersilurischen Fische von Oesel. II. Theil. Selachii, Dipnoi, Ganoidei, Pteraspidæ und Cephalaspidæ," Mem. Acad. des Sciences de St Petersloury, vol. xli. No. 5, 1893.

29. RоноN, J. V..._"Beiträge zur Classification der Palieozoischen Fische," Sitzungsb. Kön. böhm. Gesellsch. der Wisserschaften, Math. Naturw. Classe, 1896.

30. SchuÜter, C. A. T.- "Ueber Panzerfische aus dem rheinisch-westfälischen Devon," Sitzungsb. niederrh. Gesellsch., Bonn, 1887, pp. 120-128.

31. Schmid, F.-“Ueber die Pteraspiden überhaupt und ïber Pteraspis Kneri aus den obersilurischen Schichten Galiziens insbesondere," Verh. der' Kais. russischen mineralog. Gesellsch. zu St Petersburg (2), viii., 1873.

32. Traquair, R. H.- “ Notes on Carboniferous Selachii," Geol. 1/ag. (3), vol. v., 1888, pp. 81, 86.

33. Traquair, R. H.— "On the Structure of Coccosteus decipiens, Ag.,"Ann. and Ma.q. Nat. Hist. (6), vol. จ., 1890, pp. $125-136$.

34. Traquair, R. H.- "The Fossil Vertebrata of the Moray Firth Area." In Harvie-Brown and Buckley's Vertebrate Fauna of the Moray Basin. Edinburgh, 1896.

35. Traquatr, R. H.- "Additional Notes on the Fossil Fishes of the Upper Old Red Sandstone of the Moray Firth Area," Proc. Roy. Phys. Soc. Edint., vol. xiii., 1S97, pp. 376-385.

36. Traqualr, R. H.- "On Thelodus Pagei (Powrie) from the Old Red Sandstone of Forfarshire," Trans. Roy. Soc. Edinb., vol. xxxix., 1899, pp. 595-602.

37. Trautscrold, H.-"Ueber Coccosteus megalopteryx, Trd., Coccosteus obtusus and Cheliophorus Verneuili, Ag.,"Zeitschr. der deutschen geol. Gesellschaft, 1889, pp. 35-48.

38. Woodward, A. Smith.- "Catalogue of the Fossil Fishes in the British Museum," Part II., 1891.

39. Woodward, A. Smith._-"The Problem of the Primæval Sharks," Natural Sicien'e, vol. vi., 1895, pp. 38-43. 
40. Woodward, A. Smith._- Edward Drinker Cope" (obituary notice). Natural Science, vol. x., 1897, pp. 377-381.

41. Woodward, A. Smitr.--"Outlines of Vertebrate Palæontology." Cambridge, 1898.

42. Ziтtel, C. v.- "Handbuch der Palæontologie." Division I., vol. iii. pt.|1. Munich and Leipzig, 1887.

43. ZirteL, C. v.—“Grundziige der Palæontologie (Palæozoologie)." Munich and Leipzig, 1895.

\section{EXPLANATION OF THE PLATES.}

Piate I.

Thelodus Scoticus, Traq.

Fig. 1. A specimen from the "Ceratiocaris Band," Logan Water. Natural size. The head is imperfect, but the sculpture and arrangement of the scales is exceedingly well shown in places.

Fig. 2. Another specimen from the same horizon and locality. Natural size. The contour in front is somewhat obscured by distortion.

Fig. 3. A specimen from the Downtonian horizon at Seggholm, showing the shape of the body unusually well. Natural size.

Fig. 4. Another specimen from a similar horizon at Monk's Burn.

Fig. 5. Upper surface of an isolated head-scale from Logan Water, magnified twenty diameters.

Fig. 6. The same scale, from below.

Fig. 7. The same scale, from the side.

Fig. 8. Upper surface of a scale from behind the head, also from Logan Water, magnified twenty diameters.

Fig. 9. A similar scale seen from the side, magnified twenty diameters.

Fig. 10. Arrangement of the posterior scales, from the specimen represented in fig. 1. Same enlargement as in figs. 8 and 9 .

Plate II.

Thelodus planus, Traq.

Fig. 1. Entire specimen, natural size, from the "Ceratiocaris Band," Logan Water.

Fig. 2. Scales from the front; outer surface, magnified eight diameters.

Fig. 3. Scales from the caudal region, outer surface; same enlargement.

\section{Plate III.}

Lanarkia horrida, Traq.

Fig. 1. Specimen, showing the head region well, but imperfect posteriorly. Downtonian, Birkenhead Burn. Enlarged by one half.

Fig. 2. Another specimen from the same horizon and locality, showing a nearly perfect caudal extremity. Also enlarged one half.

Figs. 3-4. Isolated dermal spines, magnified twelve diameters.

Fig. 5. Natural cast of the interior of a spine, seen from above, apex broken off ; same enlargement.

Fig. 6. A group of similar spines; same enlargement. 


\section{Lanurlia spinosa, Traq.}

Fig. 7. Entire specimen, somewhat distorted on right side; natural size. Downtonian, Seggholm.

Fig. 8. Another entire specimen from the same horizon and locality; natural size.

Fig. 9. Portion of integument from a specimen from Birkenhead Burn, magnified, showing the larger dermal spines intermixed with those of minute size ; magnified nine diameters.

Figs. 10-12. Three of the larger dermal spines also from a Birkenhead Burn specimen, magnified twelve diameters.

\section{Plate IV.}

\section{Lanavkia spinosa, Traq.}

Fig. 1. A small specimen from Seggholm, in which the larger spines are very strongly marked. Enlarged one half.

Fig. 2. Portion of integument of the same specimen, magnified four diameters.

$$
\text { Lanarkia spinulosa, Traq. }
$$

Fig. 3. Imperfect specimen from the Downtonian horizon, Birkenhead Burn; natural size.

Fig. 4. Spiny integument of the same specimen, magnified six diameters.

Fig. 5. Isolated dermal spine from another specimen, magnified twenty diameters.

$$
\text { Ateleaspis tessellata, Traq. }
$$

Fig. 6. Specimen from the Downtonian horizon, Seggholm, fairly complete in front, but obliquely cut off behind.

Fig. 7. Portion of the body of another specimen; natural size.

Fig. 8. Upper lobe of the caudal fin of another specimen; natural size.

Fig. 9. Tesseræe of the surface of the head, seen in impression on the counterpart of the specimen represented in fig. 6, and magnified five diameters.

Fig. 10. $A^{\prime}$ 'squeeze in modelling wax taken from a similar part, also magnified five times.

Fig. 11. Scales from behind the head of the specimen shown in fig. 6 as seen in a squeeze in modelling wax taken from the counterpart, magnified three diameters.

Fig. 12. Scales from specimen shown in fig. 7, magnified two diameters.

All these specimens of Ateleaspis are from the Downtonian Beds of Seggholm.

\section{Plate V.}

$$
\text { Birkenia elegans, Traq. }
$$

Fig. 1. Entire specimen from Birkenhead Burn (Downtonian), enlarged one half.

Fig. 2. Another specimen from the same locality, having the body shortened up, enlarged one half.

Fig. 3. Head of another specimen from the same locility, enlarged one balf.

Fig. 4. Impression of a detached scute of the median ventral series, magnified four diameters. From Lyneslie Burn, Pentland Hills.

$$
\text { Lasanius problematicus, Traq. }
$$

Fig. 5. A specimen from Birkenhead Burn, showing the fish as it usually occurs-the ventral scutes and the gridiron-like arrangement of rods being in position with regard to each other. Enlarged by one half.

VOL. XXXIX. PART III. (NO. 32). 
Fig. 6. A specimen from Seggholm, in which the form of the head as well as of the caudal fin is shown by a carbonaceous film. The lower lobe of the caudal is slightly distorted; the body is bent nearly double. Magnified two diameters.

Fig. 7. Gridiron-like arrangement of parallel rods of both sides, vertically compressed and spread out, and showing how those of opposite sides meet together in the dorsal middle line. The left set of rods is crossed by the anterior part of the series of ventral scutes $(v)$. From Birkenhead Burn, and magnified two diameters.

Fig. 8. Left series of parallel rods in a specimen from Seggholm; enlarged by one half. The peculiar chain of ossicles or rodlets is well seen in front of the anterior rod.

Fig. 9. The three uppermost rodlets in a specimen from Seggholm; magnified two diameters.

Fig. 10. Outline of a usual form of the ventral scutes, seen from the side. Birkenhead Burm; magnified four diameters.

Fig. 11. Another form, in which the elevation is less. Seggholm ; magnified four diameters.

\section{Lasanius armatus, Traq.}

Fig. ${ }_{i}^{12}$. The more perfect of the two specimens known, showing in a carbonaceous film the blunt form of the head, and posteriorly the heterocercal caudal fin with its rays distinctly preserved. Seggholm; magnified three diameters.

Fig. 13. Outlines of two of the ventral scutes of the other specimen, magnified four diameters. 
Trans Roy Soc Edin ${ }^{r}$

Vol. XXXIX.

$D^{R}$ R.H.TRAQUAIR ON SILURIAN FISHES, PLATE
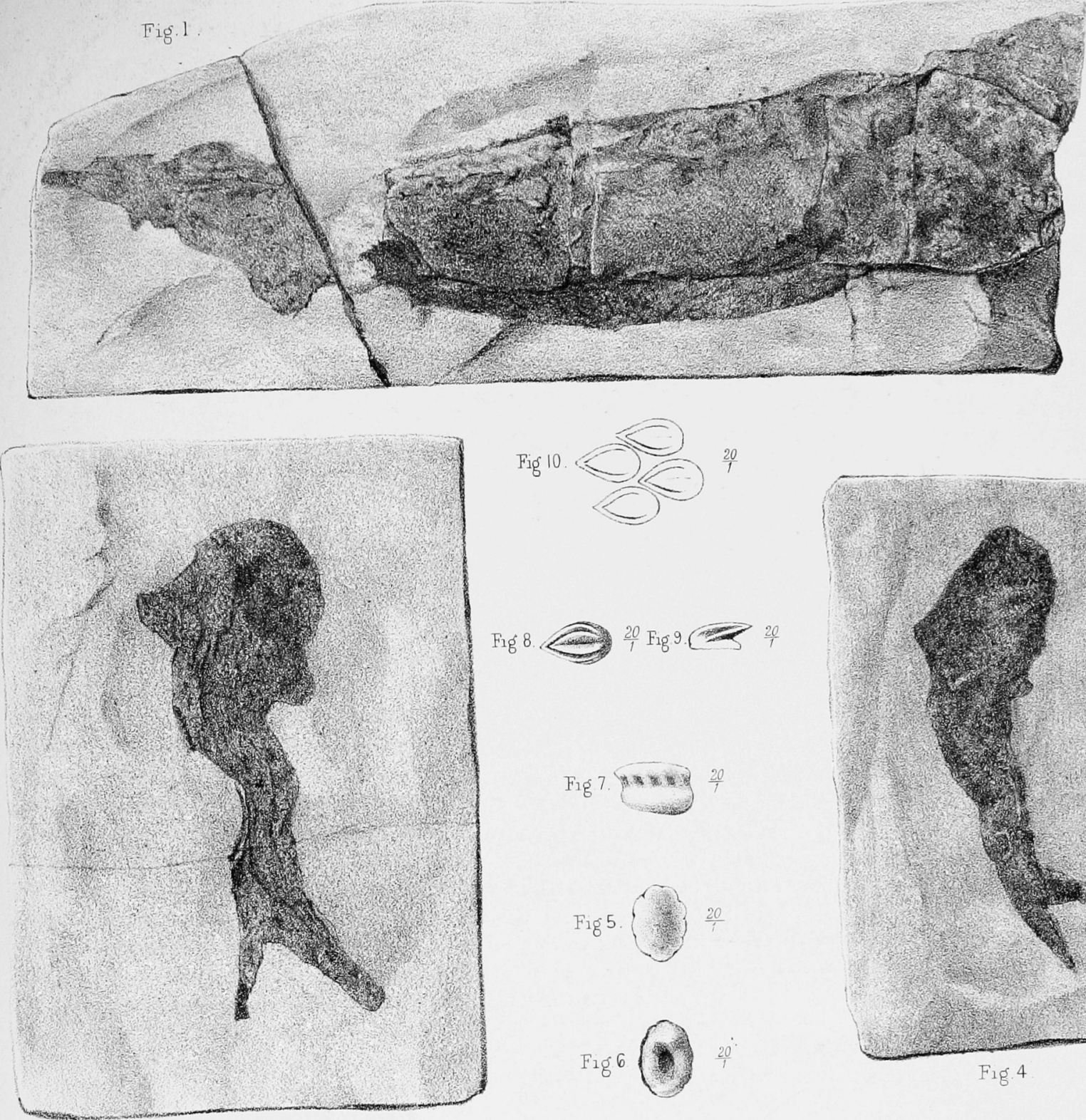

Fig 10.

$\mathrm{Fig} 8 \Longleftrightarrow \frac{20}{1} \mathrm{Fig}^{9} \longrightarrow \frac{20}{1}$

Fig $7.5 \times x=\frac{20}{T}$

Fig $5 .\left\{\frac{20}{1}\right.$

Fig 6 (1)

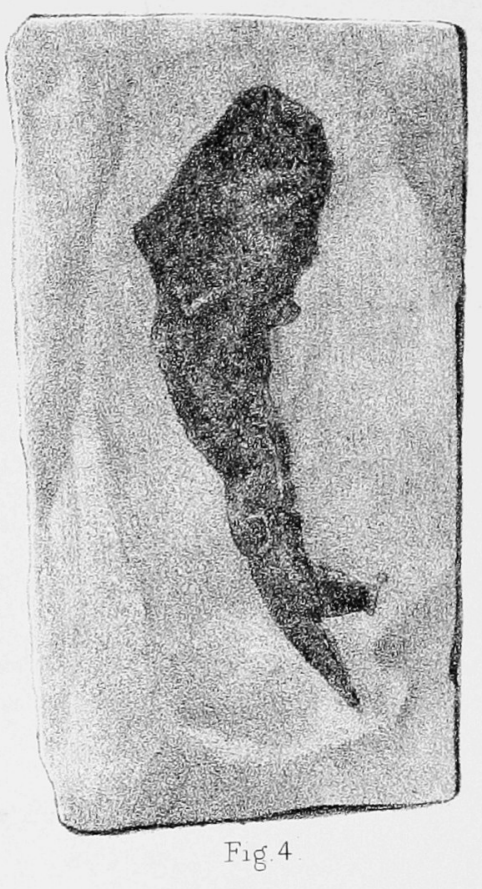

Fig. 3

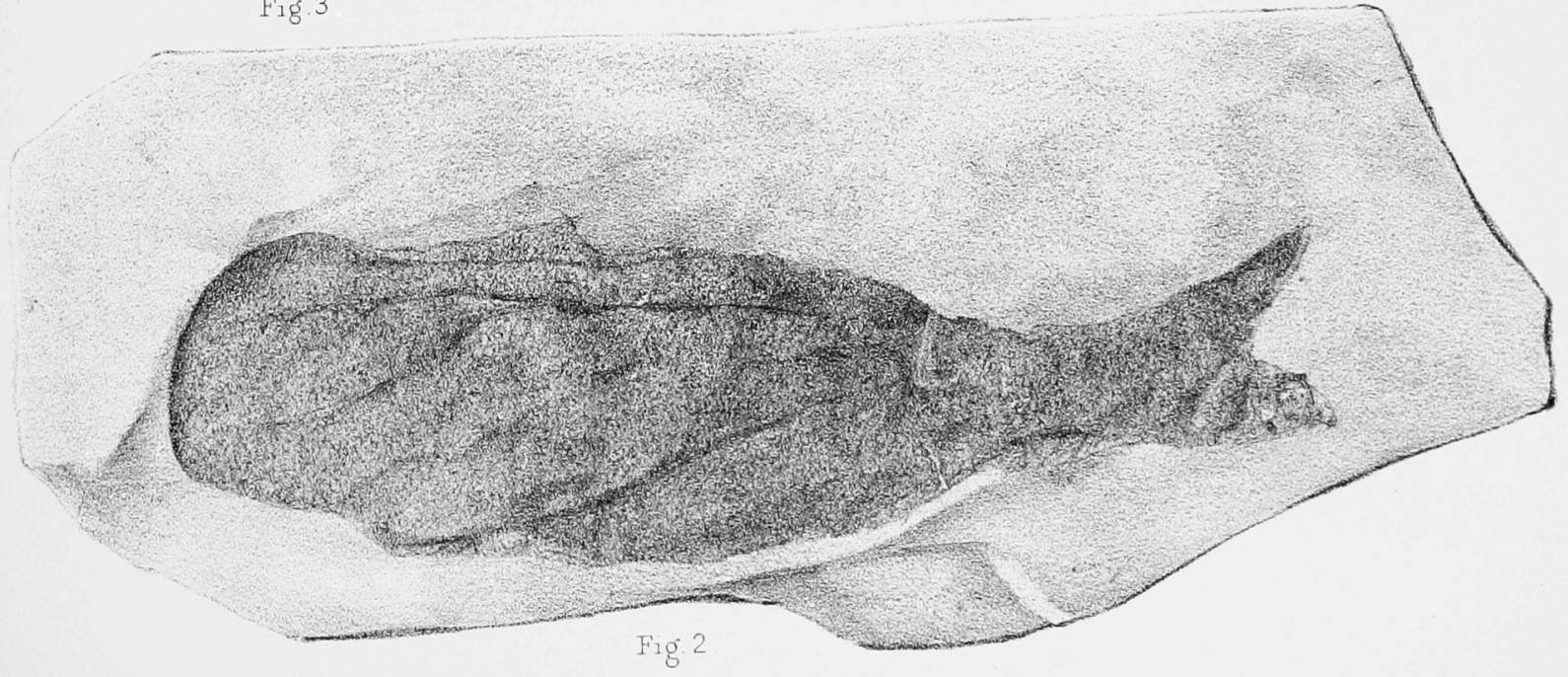


D?.R.H.TRAQUAIR ON SILURIAN FISHES, PLATE II.

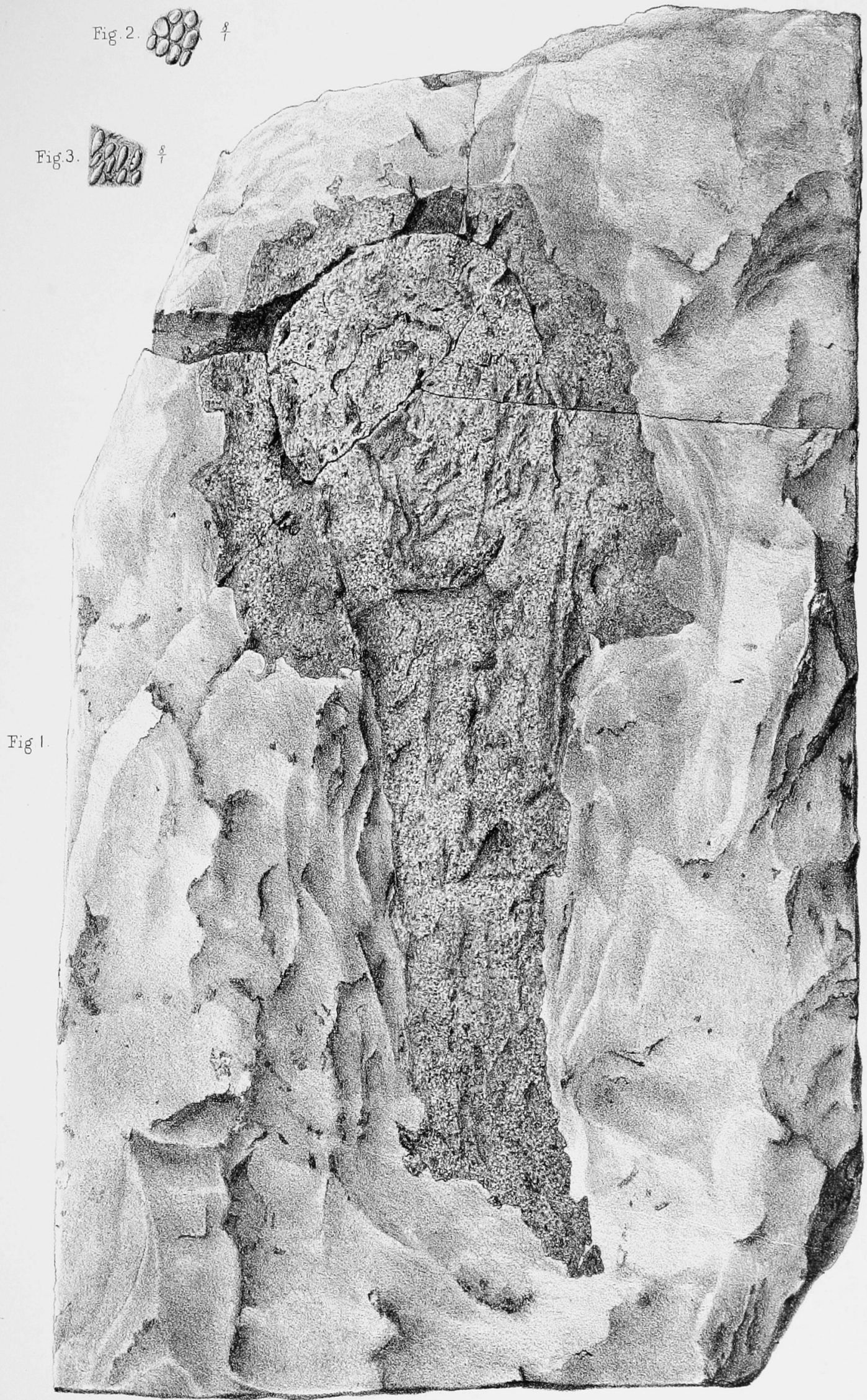



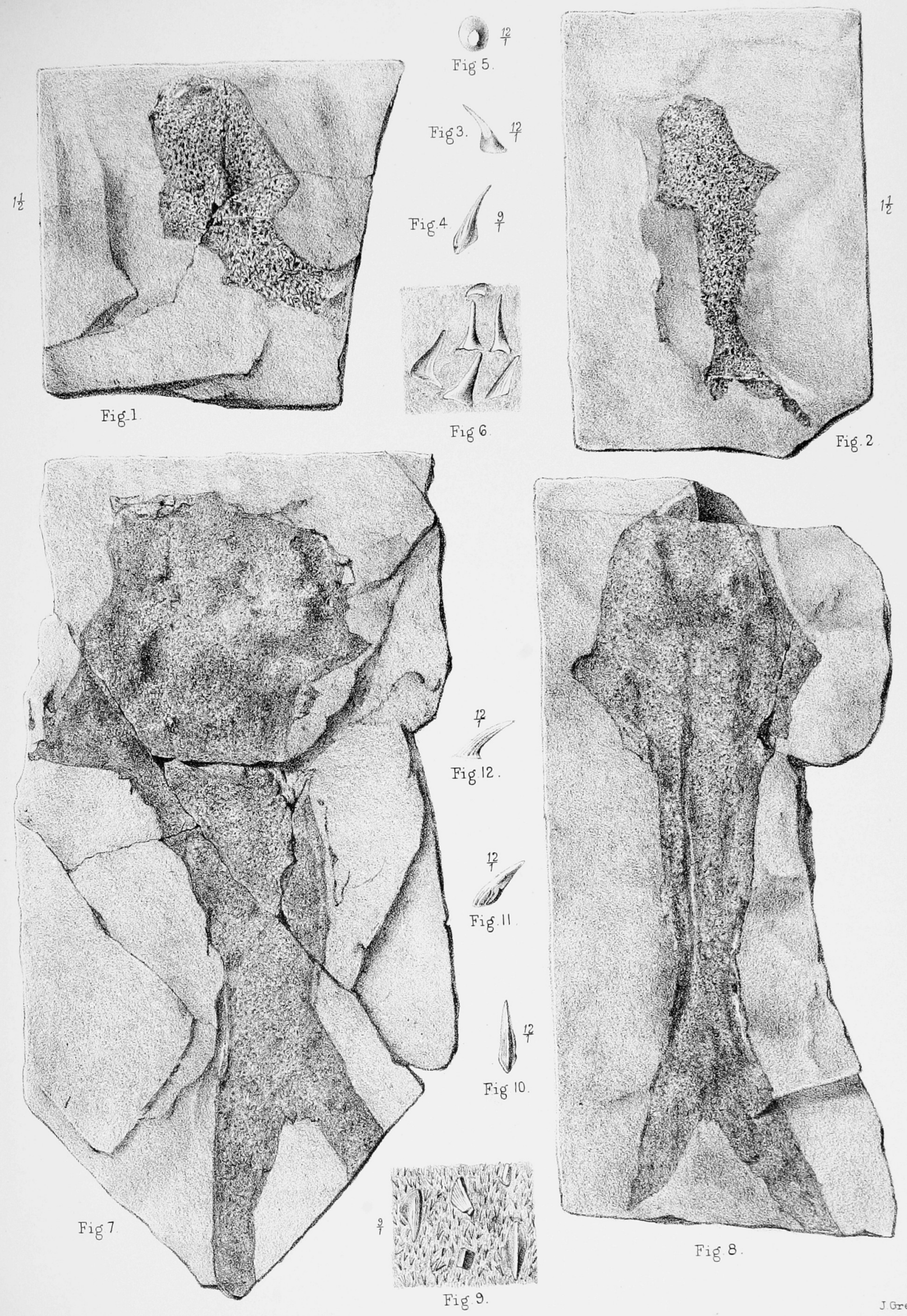
Trans. Roy. Soc Edmer

DR.R.H.TRAQUAIR ON SILURIAN FISHES, PLATEIV.

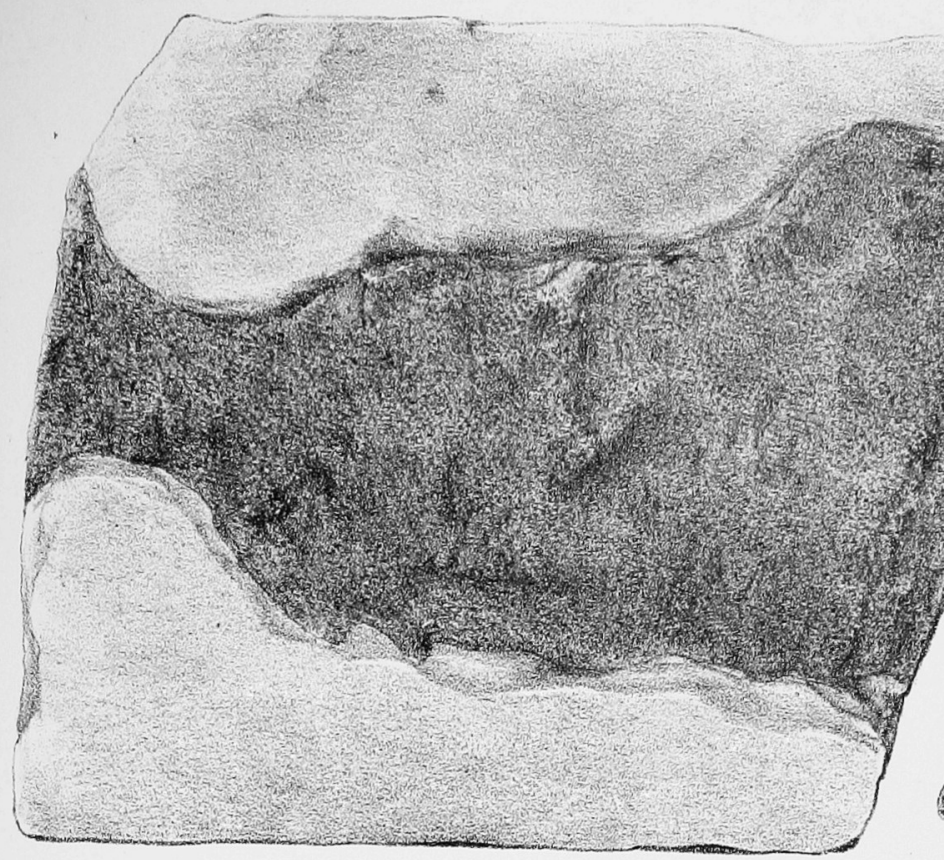

Fig. 3

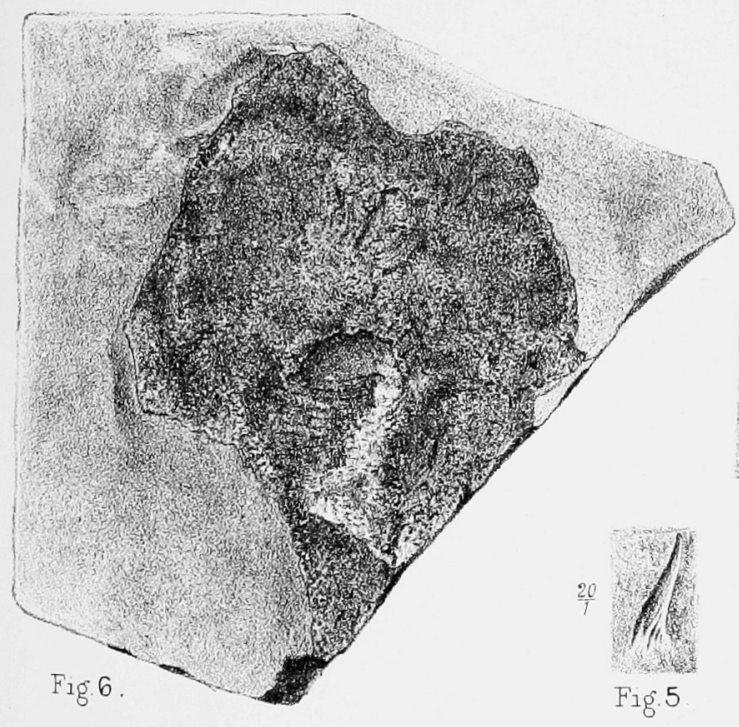

Fig. $\frac{60 \%}{40 \%}$

Fig. 10.

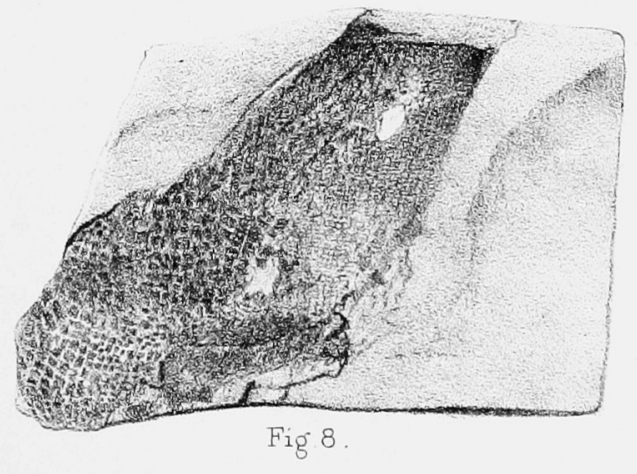

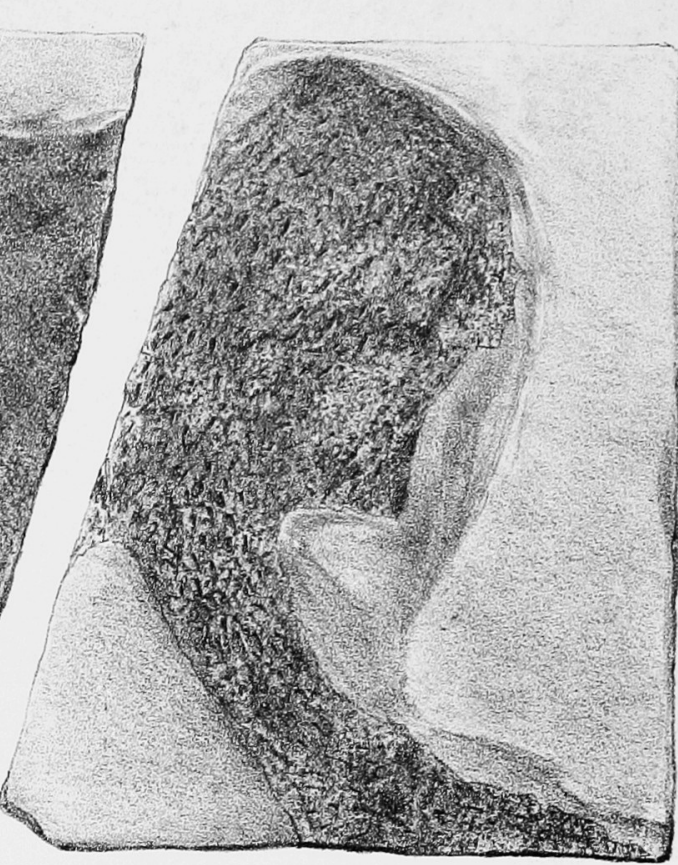

Fig 1 .
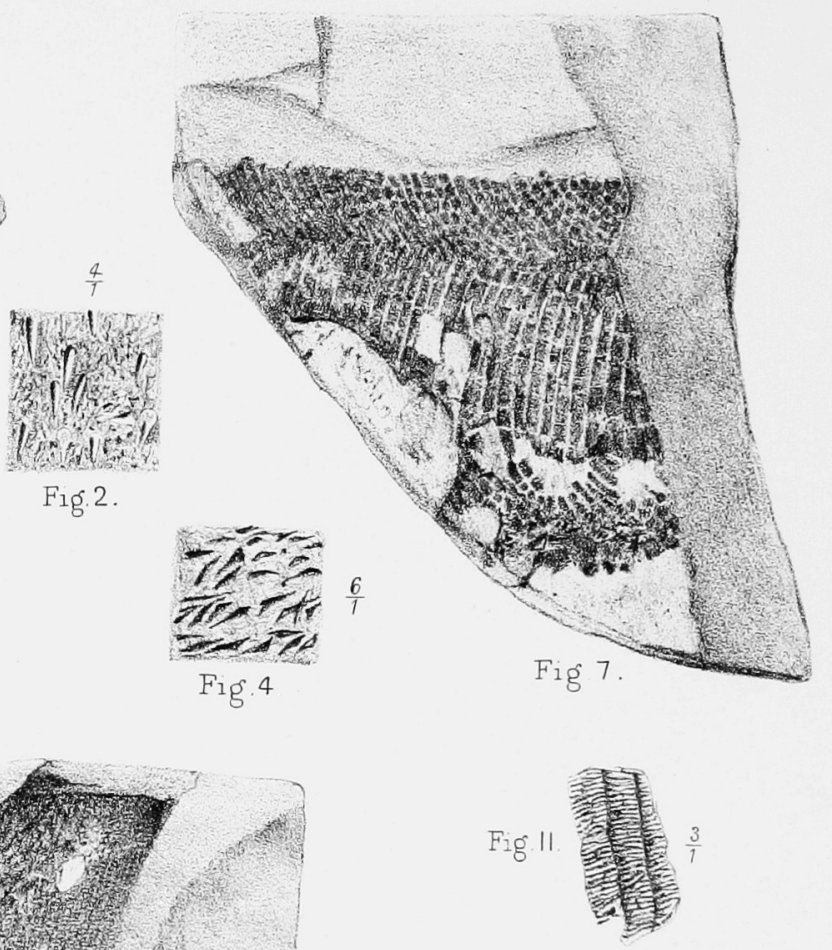

Fig $12 . \frac{1}{1}$ 
Trans Roy. Soc Edin?

DR.R.H.TRAQUAIR ON SILURIAN FISHES, PLATE V.

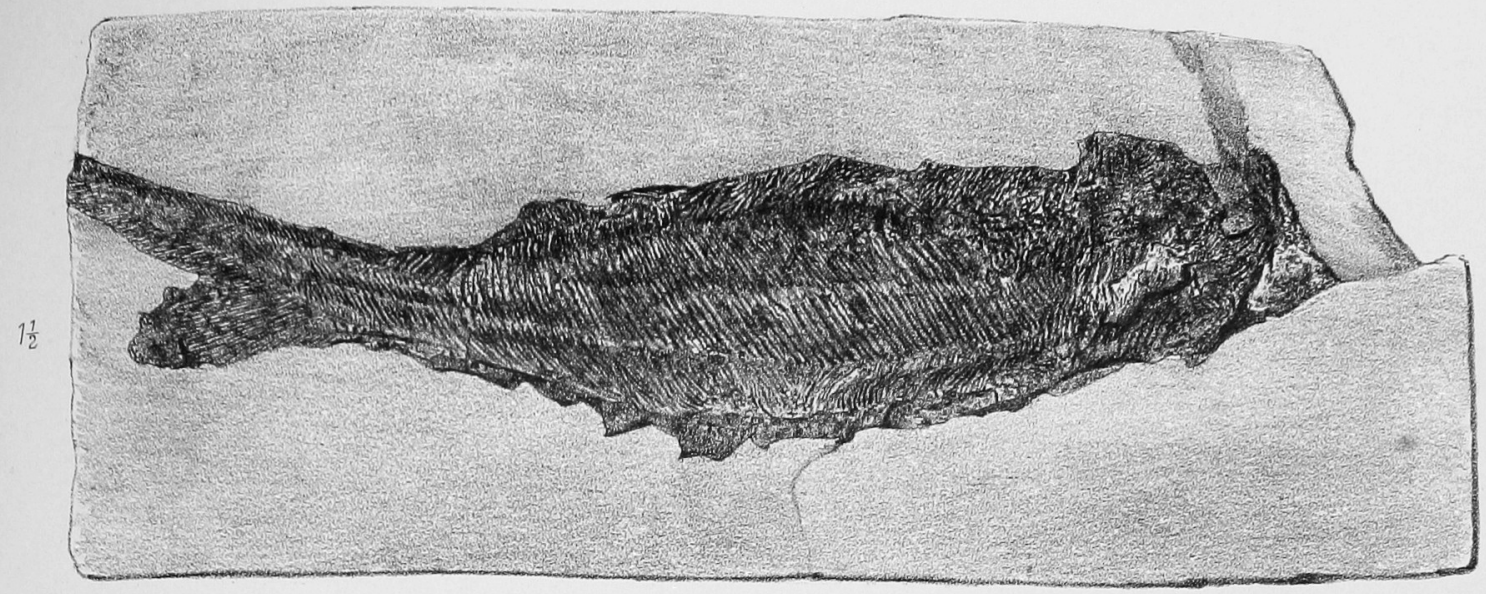

Fig.l.

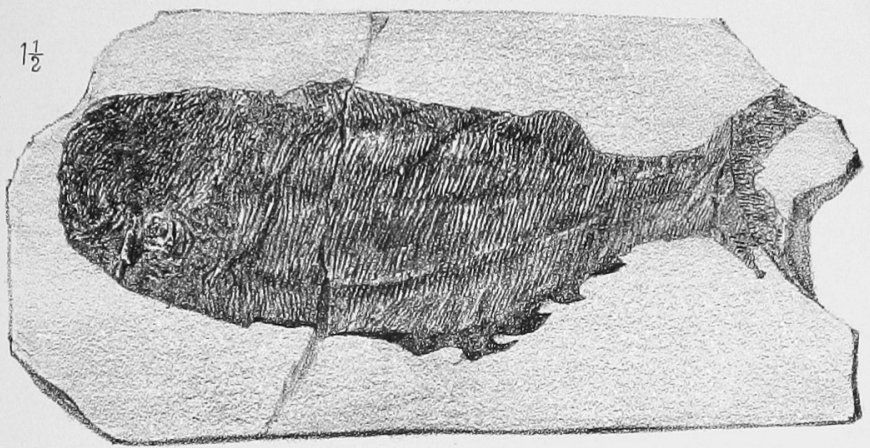

Fig.2

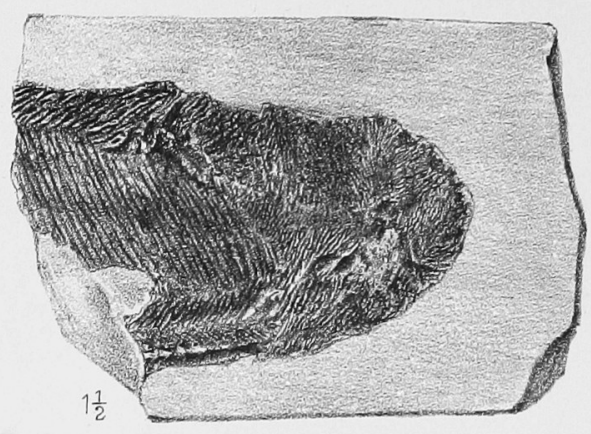

Fig. 3

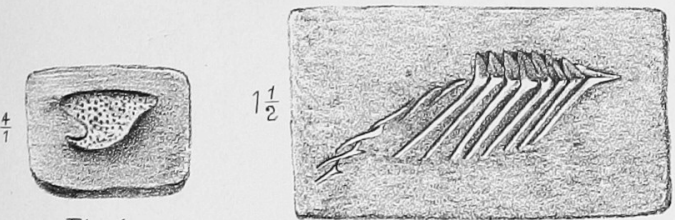

Fig. 4
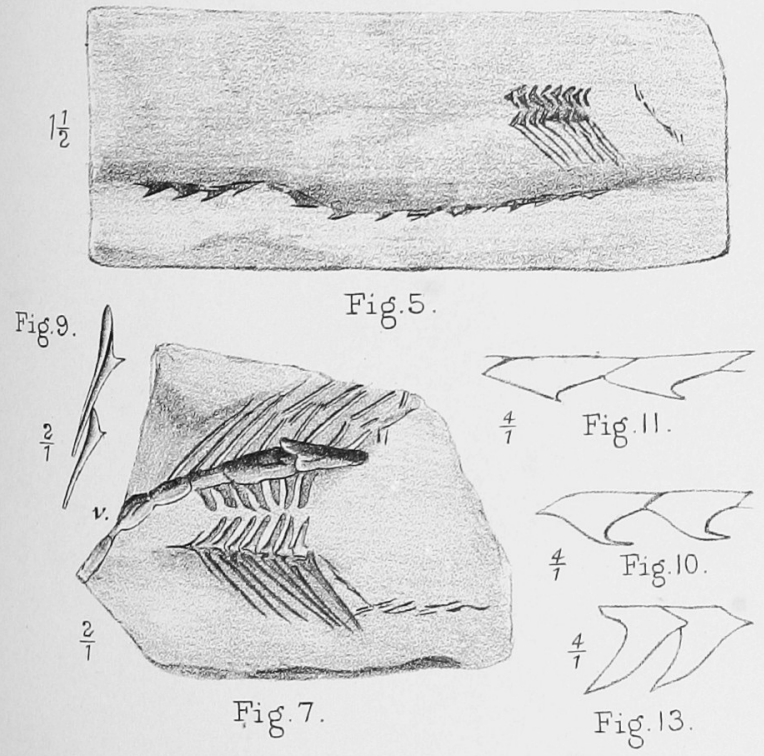

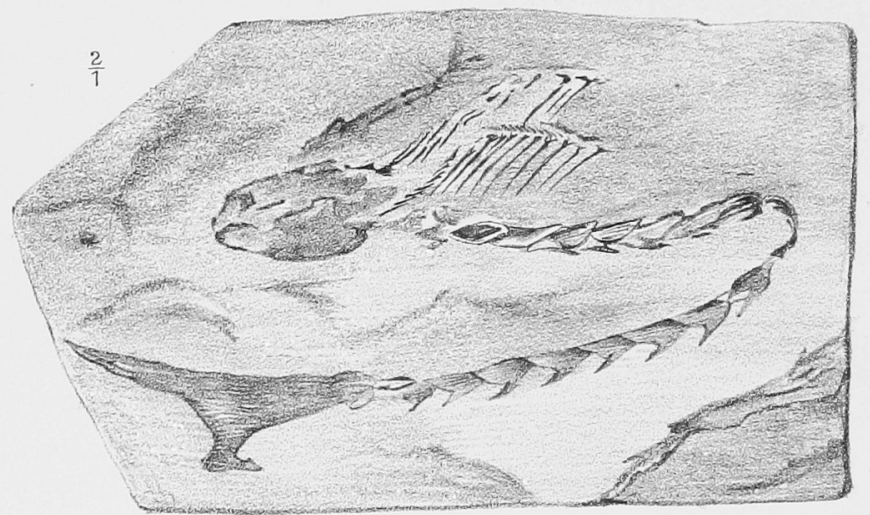

Fig.6.

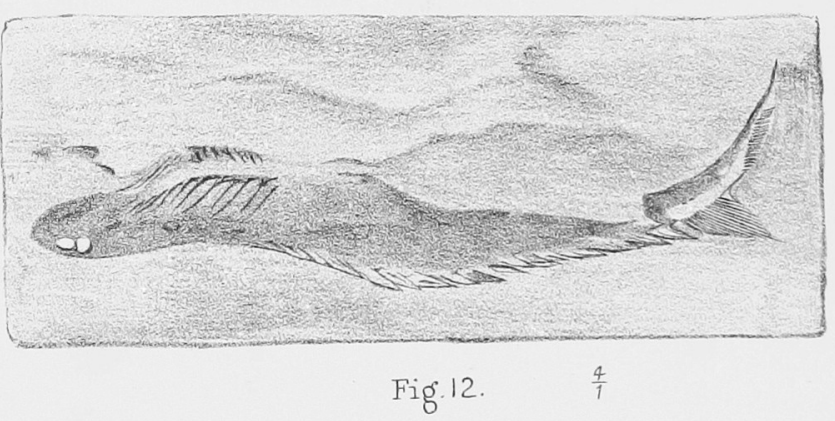

